\title{
Chlorophyll Extraction and Storage Studies on Selected Vegetables (Bitter Leaf - Vernonia Amygdalina, Pawpaw Leaf - Carica Papaya and Pumpkin Leaf - Telfairia Occidentalis)
}

\author{
Irede, L. Egwonor*, Asishana P. Onivefu \\ Department of Chemistry University of Benin, Benin City, Edo State, Nigeria
}

*Corresponding Author: Irede, L. Egwonor, Department of Chemistry University of Benin, Benin City, Edo State, Nigeria

\begin{abstract}
Chlorophyll is the term used for several closely related pigments found in cyanobacteria and the chloroplast of algae and plants. Chlorophyll is the green pigment responsible for the color of leaves. Its presence in leaves is crucial for photosynthesis. Chlorophyll absorbs light most strongly in the blue portion of the electromagnetic spectrum, followed by the red portion. Conversely, it is a poor absorber of green and neargreen portions of the spectrum, hence the green color of chlorophyll containing tissues. This study evaluated the effect of extraction solvent and storage on chlorophyll extracted from selected vegetables (bitter leaf, pawpaw leaf and pumpkin leaf), It also observed the absorbance pattern at 430nm for chlorophyll a and 660nm for pheophytin a (a derivative of chlorophyll) for extracts stored at room temperature and water activity $\left(a_{w}\right)$ of 0.33 and 0.75 during a one month storage period. Uv-visible scans were carried out weekly for all extracts during the storage period. Absorbance measurement at 430nm and 660nm showed that initially, after extraction, the absorbance values of extracts followed according to the order of polarity of the solvents used for extraction. The order of polarity was deionized distilled water > ethanol > acetone > petroleum ether > nhexane. Uv-visible scan for extracts stored at room temperature, initially after extraction and after one month storage period showed the dominant presence of chlorophyll a and chlorophyll $b$. Uv-visible scan for extracts stored at water activity $\left(a_{w}\right)$ of 0.33 showed the conversion of chlorophyll b at 467nm,473nm to chlorophyll a at $448 \mathrm{~nm}, 671 \mathrm{~nm}$ after one month storage period and conversion of chlorophyll a to an unknown compound which absorbs at $331 \mathrm{~nm}$ or $333 \mathrm{~nm}$. Uv-visible scan for extracts stored at water activity $\left(a_{w}\right)$ of 0.75 showed the conversion of chlorophyll $a$ and chlorophyll b to an unknown compound which absorbs at 331nm or $333 \mathrm{~nm}$. The $\mathrm{pH}$ measured for extracts stored at water activity $\left(a_{w}\right)$ of 0.33 showed increase in acidity after one month of storage. $\mathrm{pH}$ measured for extracts stored at water activity $\left(a_{w}\right)$ of 0.75 showed $\mathrm{pH}$ change to slightly alkaline except for pawpaw leaf extracts which showed increase in acidity. The difference between the initial and final specific gravity shows reduction in the chlorophyll content of extracts after one-month storage period.
\end{abstract}

\section{INTRODUCTION}

Chlorophyll is a term used for several closely related green pigments found in cyanobacteria and the chloroplasts of algae and plants. Its name is derived from the Greek words chloros (green) and phyllon (leaf). Chlorophyll is an extremely important biomolecule, critical in photosynthesis, which allows plants to absorb energy from light. Chlorophyll absorbs light most strongly in the blue portion of the electromagnetic spectrum, followed by the red portion. Conversely, it is a poor absorber of green and neargreen portions of the spectrum, hence the green color of chlorophyll-containing tissues (WikiDoc, 2015).

The energy to drive the chemical reactions of photosynthesis comes from the sunlight absorbed by the chlorophyll molecules. Hence, the first step in photosynthesis is the absorption of visible light from the sun by chlorophyll molecules. The chlorophyll molecules then transfer the light energy to chloroplasts, the reaction center of photosynthesis. In this way light energy is converted to chemical energy for converting $\mathrm{CO}_{2}$ into carbohydrates.

The overall reaction for photosynthesis is:

$6 \mathrm{CO}_{2}+6 \mathrm{H}_{2} \mathrm{O}+h v \rightarrow \mathrm{C}_{6} \mathrm{H}_{12} \mathrm{O}_{6}+6 \mathrm{O}_{2}$

This overall equation for photosynthesis is deceptively simple. In fact, a series of complex reactions must occur in a coordinated manner for the synthesis of carbohydrates. Without light photosynthesis cannot take place; and hence the absorption of light by chlorophyll is the first step in photosynthesis. 
Chlorophyll was first isolated by Joseph BienaiméCaventou and Pierre Joseph Pelletier in 1817. In an extraction by Zvezdanoicet al, (2009), Fresh plant leaves were first depleted from the mid ribs and washed with cold water. The extraction and re-extraction mixtures were methanol and petroleum ether in a 2:1 ratio, and petroleum ether and diethyl ether (1:1), respectively.

Chlorophylls belong to the group of the most important bioorganic molecules; they are the principal pigments in photosynthesis, capable of light energy absorbing and its conversion to "chemical energy" by the formation of chemical compounds rich in energy (needed for the biosynthesis of carbohydrates and other compounds in photosynthetic organisms such as plants, algae and photosynthetic bacteria (Scheer, 1991 and 2006).The chlorophylls comprise a group of more than 50 tetrapyrrolic pigments with common structural elements and function (Scheer, 2006).

\subsection{Chlorosis}

Chlorosis is derived from the word chloris or from the Greek khloros meaning greenish-yellow or pale green. In botany, chlorosis is a condition in which leaves produce insufficient chlorophyll (English Wikipedia, 2015).

\subsection{Chloroplast}

Chloroplasts are organelles, specialized subunits found in plant cells and eukaryotic algae that conduct photosynthesis. Chloroplasts absorb sunlight and use it in conjunction with water and carbon dioxide gas to produce food for the plant. Chloroplasts capture light energy from the sun to produce the free energy stored in ATP and NADPH through a process called photosynthesis (Olson, 2006).

\subsection{Uses of Chlorophyll}

Chlorophyll is present abundantly in nature and due to its critical light harvesting role in photosynthesis, it is vital to the survival of both the plant and animal kingdoms (Humphrey, 2004). Chlorophyll selectively absorbs light in the red and blue regions and therefore emits a green colour. Photosynthesis is a process which uses this harvested light energy together with water and carbon dioxide to produce oxygen and carbohydrates; as such, it converts solar energy into chemical energy. The products from this chemical process reflect its significance, with carbohydrates being the primary building block for plants and oxygen being necessary for the survival of animal kingdom (Humphrey, 2004). The importance of photosynthesis for life on earth is further highlighted by plants forming the basis of all food chains. Chlorophyll is a compound that is decomposed and reproduced continuously in significant amounts both terrestrially and in the oceans. It is estimated that 1.2 billion tons of chlorophyll are produced annually in the planet (Humphrey, 2004).

Chlorophyll is used as a colouring agent due to its selective absorbance of light of certain wavelengths and its consequent green colour. Changes in market demands and legislation have resulted in the requirement of natural colouring agents to be used in food products in preference to artificial colourings (Spears, 1988). Colouring is essential for both consumers and manufacturers, as many foods lose their original colours due to chemical processes they undergo. Consumers demand products of original appearance, while manufacturers desire uniformity for all products (Spears, 1988; Timberlake and Henry 1988). Chlorophyll in plants is confined in chloroplasts where it is not only complexed with phospholipids, polypeptides and tocopherols but also protected by a hydrophobic membrane (Humphrey, 2004). When chlorophyll is removed from this protective environment, its magnesium ion becomes unstable and may easily be displaced by a weak acid. In order to overcome this problem, the magnesium ion is often substituted with a copper ion to form a highly stable blue/green complex (Humphrey, 2004; Timberlake and Henry, 1988). Although chlorophyll is a natural food colouring agent, there are disadvantages associated with its use. Its pigment content is not precisely known, and it tends to be unstable under the different $\mathrm{pH}$ conditions of the foods to which it is added. Additionally, it is more expensive than artificial colourings (Spears, 1988) and it must undergo a chemical modification by replacing the magnesium centre with a copper ion to improve its stability as a food colouring agent. Since the copper complex is not absorbed by the body and is removed in its entirety as an excretion product, it is safe and permitted to be used in most countries as a food additive. However, the concentration of free ionizable copper in the colouring must be kept below 200ppm under current regulations (Humphrey, 2004; Timberlake and Henry, 1988). 
Chlorophyll and its derivatives are also used widely in pharmaceutical products. Chlorophyll has been found to accelerate wound healing by more than $25 \%$ in some studies. Since chlorophyll stimulates tissue growth, it prevents the advancement of bacteria and speeds up the wound healing process (Smith and Livingston, 1945 and Carpenter, 1949). Chlorophyll is similar in chemical structure to haemoglobin and, as such, is predicted to stimulate tissue growth in a similar fashion through the facilitation of a rapid carbon dioxide and oxygen interchange (Horwitz, 1951). Because of this property, chlorophyll is used not only in the treatment of ulcers and oral sepsis but also in proctology. Chronic ulcer is a significant health problem in society, with lengthy periods required for its treatment (Cady and Morgan, 1948). The discharge from the ulcer and its characteristic odour also improved significantly after a few days of chlorophyll treatment (Cady and Morgan, 1948). The same properties which make chlorophyll a key compound in the treatment of ulcers also make it vital in the treatment of post-operative wounds from rectal surgery. When proctologists remove large areas of tissue, healing can be difficult and the area of the removed tissue tends to be painful (Horwitz, 1951).

\subsection{Chemical Structure of Chlorophyll}

Chlorophyll is a chlorinpigment, which is structurally similar to and produced through the same metabolic pathway as other porphyrin pigments such as heme. The porphyrins are an important class of naturally occurring macrocyclic compounds found in biological compounds that play a very important role in the metabolism of living organisms.

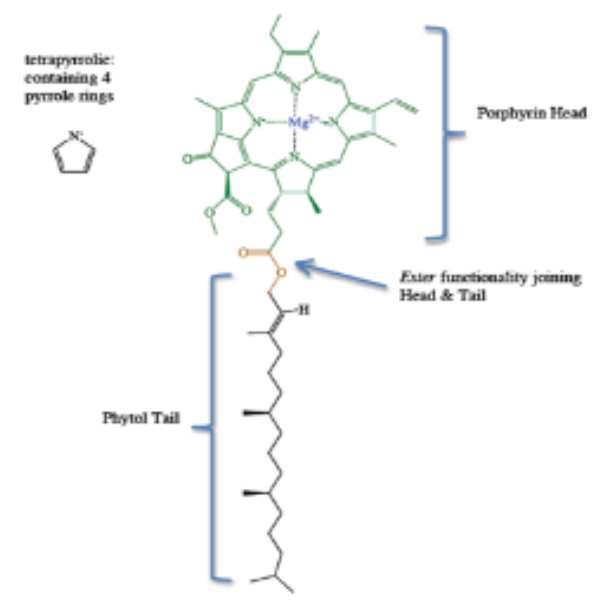

Fig1.0. Structure of chlorophyll a

In 1967, the last remaining stereochemical elucidation was completed by Ian Fleming in 1967 and in 1990 Woodward and co-authors published an updated synthesis (Woodward, 1990) Chlorophyll f was announced to be present in cyanobacteria and other oxygenic microorganisms that form stromatolites in 2010; (Jabr, 2010) a molecular formula of $\mathrm{C}_{55} \mathrm{H}_{70} \mathrm{O}_{6} \mathrm{~N}_{4} \mathrm{Mg}$ and a structure of (2-formyl)-chlorophyll $a$ were deduced based on NMR, optical and mass spectra (Chen, 2010). Pheophytin (Pheo) is a chlorophyll derivative, demetallized chlorophyll or simply chlorophyll without central $\mathrm{Mg}$-atom (Jeffery et al., 1996; Shioiand Takamiya 1996) as shown in the Figure below.

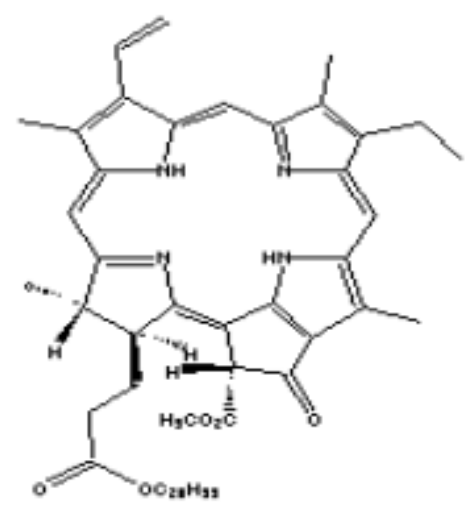

Fig1.2. Structure of Pheophytin a (Raven et al., 2005) 
Chlorophyllide (Chlid) is a derivative of chlorophyll, namely, chlorophyll without phytol chain in C17position as shown in Figure below.

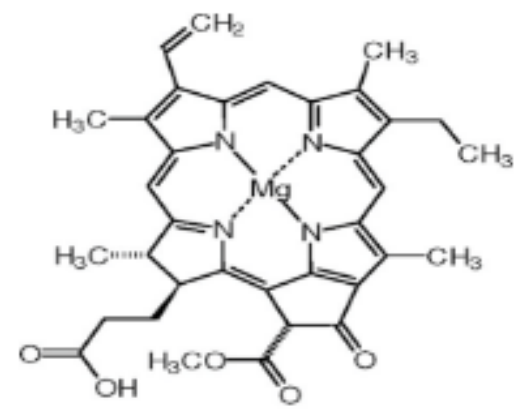

Fig1.3. Structure of Chlorophyllide a (Raven et al, 2005)

Table1.0. The summary of the chlorophylls and their properties

\begin{tabular}{|c|c|c|c|c|c|c|}
\hline & $\frac{\text { Chlorophyll }}{\underline{\mathbf{a}}}$ & $\frac{\text { Chlorophyll }}{\underline{\mathbf{b}}}$ & $\frac{\text { Chlorophyll }}{\underline{\text { c1 }}}$ & $\frac{\text { Chlorophyll }}{\underline{\text { c2 }}}$ & $\frac{\text { Chlorophyll }}{\underline{\mathbf{d}}}$ & $\frac{\text { Chlorophyll }}{\underline{\mathbf{f}}}$ \\
\hline $\begin{array}{c}\text { Molecular } \\
\text { formula }\end{array}$ & $\begin{array}{c}\mathrm{C}_{55} \mathrm{H}_{72} \mathrm{O}_{5} \mathrm{~N}_{4} \mathrm{M} \\
\mathrm{g}\end{array}$ & $\begin{array}{c}\mathrm{C}_{55} \mathrm{H}_{70} \mathrm{O}_{6} \mathrm{~N}_{4} \mathrm{M} \\
\mathrm{g}\end{array}$ & $\begin{array}{c}\mathrm{C}_{35} \mathrm{H}_{30} \mathrm{O}_{5} \mathrm{~N}_{4} \mathrm{M} \\
\mathrm{g}\end{array}$ & $\begin{array}{c}\mathrm{C}_{35} \mathrm{H}_{28} \mathrm{O}_{5} \mathrm{~N}_{4} \mathrm{M} \\
\mathrm{g}\end{array}$ & $\begin{array}{c}\mathrm{C}_{54} \mathrm{H}_{70} \mathrm{O}_{6} \mathrm{~N}_{4} \mathrm{M} \\
\mathrm{g}\end{array}$ & $\begin{array}{c}\mathrm{C}_{55} \mathrm{H}_{70} \mathrm{O}_{6} \mathrm{~N}_{4} \mathrm{M} \\
\mathrm{g}\end{array}$ \\
\hline C2 group & $-\mathrm{CH}_{3}$ & $-\mathrm{CH}_{3}$ & $-\mathrm{CH}_{3}$ & $-\mathrm{CH}_{3}$ & $-\mathrm{CH}_{3}$ & $-\mathrm{CHO}$ \\
\hline C3 group & $-\mathrm{CH}=\mathrm{CH}_{2}$ & $-\mathrm{CH}=\mathrm{CH}_{2}$ & $-\mathrm{CH}=\mathrm{CH}_{2}$ & $-\mathrm{CH}=\mathrm{CH}_{2}$ & $-\mathrm{CHO}$ & $-\mathrm{CH}=\mathrm{CH}_{2}$ \\
\hline C7 group & $-\mathrm{CH}_{3}$ & $-\mathrm{CHO}$ & $-\mathrm{CH}_{3}$ & $-\mathrm{CH}_{3}$ & $-\mathrm{CH}_{3}$ & $-\mathrm{CH}_{3}$ \\
\hline C8 group & $-\mathrm{CH}_{2} \mathrm{CH}_{3}$ & $-\mathrm{CH}_{2} \mathrm{CH}_{3}$ & $-\mathrm{CH}_{2} \mathrm{CH}_{3}$ & $-\mathrm{CH}=\mathrm{CH}_{2}$ & $-\mathrm{CH}_{2} \mathrm{CH}_{3}$ & $-\mathrm{CH}_{2} \mathrm{CH}_{3}$ \\
\hline C17 group & $\begin{array}{c}- \\
\mathrm{CH}_{2} \mathrm{CH}_{2} \mathrm{COO} \\
\text {-Phytyl }\end{array}$ & $\begin{array}{c}- \\
\mathrm{CH}_{2} \mathrm{CH}_{2} \mathrm{COO} \\
\text {-Phytyl }\end{array}$ & $\begin{array}{c}- \\
\mathrm{CH}=\mathrm{CHCOO} \\
\mathrm{H}\end{array}$ & $\begin{array}{c}- \\
\mathrm{CH}=\mathrm{CHCOO} \\
\mathrm{H}\end{array}$ & $\begin{array}{c}- \\
\mathrm{CH}_{2} \mathrm{CH}_{2} \mathrm{COO} \\
\text {-Phytyl }\end{array}$ & $\begin{array}{c}- \\
\mathrm{CH}_{2} \mathrm{CH}_{2} \mathrm{COO} \\
- \text { Phytyl }\end{array}$ \\
\hline $\begin{array}{l}\mathrm{C} 17-\mathrm{C} 18 \\
\text { bond }\end{array}$ & $\begin{array}{c}\text { Single } \\
\text { (chlorin) }\end{array}$ & $\begin{array}{c}\text { Single } \\
\text { (chlorin) }\end{array}$ & $\begin{array}{c}\text { Double } \\
\text { (porphyrin) }\end{array}$ & $\begin{array}{c}\text { Double } \\
\text { (porphyrin) }\end{array}$ & $\begin{array}{l}\text { Single } \\
\text { (chlorin) }\end{array}$ & $\begin{array}{c}\text { Single } \\
\text { (chlorin) }\end{array}$ \\
\hline $\begin{array}{c}\text { Occurrenc } \\
\mathrm{e}\end{array}$ & Universal & Mostly plants & Various algae & Various algae & $\begin{array}{c}\text { Cyanobacteri } \\
\text { a }\end{array}$ & $\begin{array}{c}\text { Cyanobacteri } \\
\mathrm{a}\end{array}$ \\
\hline
\end{tabular}

\subsection{Chlorophyll and Photosynthesis}

Photosynthesis is the process by which plants, some bacteria, and some protistans use the energy from sunlight to produce sugar, which cellular respiration converts into ATP, the "fuel" used by all living things. The conversion of unusable sunlight energy into usable chemical energy, is associated with the actions of the green pigment chlorophyll. Most of the time, the photosynthetic process uses water and releases the oxygen that we absolutely must have to stay alive.

$6 \mathrm{H}_{2} \mathrm{O}+6 \mathrm{CO}_{2}-------->\mathrm{C}_{6} \mathrm{H}_{12} \mathrm{O}_{6}+6 \mathrm{O}_{2}$

Plants are the only photosynthetic organisms to have leaves (and not all plants have leaves). A leaf may be viewed as a solar collector crammed full of photosynthetic cells.

\subsection{Bitter Leaf (Vernonia amygdalina)}

Vernonia amygdalina is a multipurpose and rapid regenerating soft wooded shrub of 2 to $10 \mathrm{~m}$ tall with petiolate leaves of around $6 \mathrm{~mm}$ in diameter. This plant has been named differently by different ethnics around the world. It is a species under the genus Vernonia Schreb (Family: Compositae; Order: Asterales; S/C: Asteridae; Classes: Dicotyledons) which contains about 1000 species. More than 500 of these Vernonia plants are distributed in Africa and Asia, approximately 300 in Mexico, Central and South America and around 16 can be found in the United States (Yeap et. al., 2010).

\subsection{Fluted pumpkin (Telfairi aoccidentalis)}

Fluted pumpkin (Telfairi aoccidentalis, Family: Curcubitaceae) probably originated from the south eastern Nigeria, and is widely distributed among the Igbo speaking people, particularly around Imo 
state, Nigeria (Esiaba, 1982; Burkill, 1985; Akoroda, 1990), where it has the widest diversity (variation in pod and seed colour, seed and plant vigour, anthocyanin content of leaves and petioles or shoots, leaf size and their succulence, dioecious or monoecious plants).

\subsection{Pawpaw Leaf (Carica papaya)}

Papaya (Carica papaya) is commonly known for its food and nutritional values throughout the world. The medicinal properties of papaya fruit and other parts of the plant are also well known in traditional system of medicine. Each part of papaya tree possesses economic value when it is grown on a commercial scale (Krishna et al., 2008). Even though the active components are normally extracted from all parts of the plant, the concentration of these components vary from structure to structure. However, parts known to contain the highest concentration of the principles are preferred for therapeutic purposes and it can either be the leaves, stem, barks, roots, bulks, corms, rhizomes, woods, flowers, fruits, and the seeds (Kafaru, 1994).

\section{Materials AND Methods}

The materials and methods used in this research work are outlined as follows

\begin{tabular}{|c|c|c|}
\hline Solvents & Plant Materials & Instruments \\
\hline Deionized distilled water & Bitter leaf & T80UV/Visible \\
\hline Hexane & Pawpaw leaf & Eurosonic Blender \\
\hline Petroleum Ether & Pumpkin leaf & Jennyway pH meter \\
\hline Acetone & & Desiccator \\
\hline Ethanol & & Cuvette \\
\hline Magnesium chloride & & Beakers \\
\hline Sodium Chloride & & Funnel \\
\hline & & Sieve \\
\hline & & Picometer bottle \\
\hline
\end{tabular}

\subsection{Collection of samples}

Fresh pawpaw leaf, bitter leaf and pumpkin leaf were collected from the department of Plant Biotechnology in a black polyethylene bag to shelter the leaves the leaves from light.

\subsection{Chlorophyll Extraction}

Extraction of chlorophyll was done using five different solvents

\subsubsection{Extraction with Deionized Distilled Water}

$10 \mathrm{~g}$ of fresh bitter leaf was put in $200 \mathrm{ml}$ of deionized distilled water in a blender and blended to crush the plant cell for five (5) minutes and sieved using sieves of three (3) different pore sizes. The filtrate was taken for initial scan in the UV/visible wavelength range $(200-800 \mathrm{~nm})$ using UV/visible spectrophotometer. Absorbance of filtrate was also measured at $430 \mathrm{~nm}$ and $660 \mathrm{~nm}$. The filtrate was stored at room temperature and at water activity of 0.33 and 0.75 . The UV/visible scan and absorbance measurements were carried out immediately after extraction and repeated weekly for four (4) weeks (one month) for samples stored at room temperature and repeated at the end of one month for samples stored at 0.33 and 0.75 water activity. The same procedure was repeated for pawpaw leaf and pumpkin leaf.

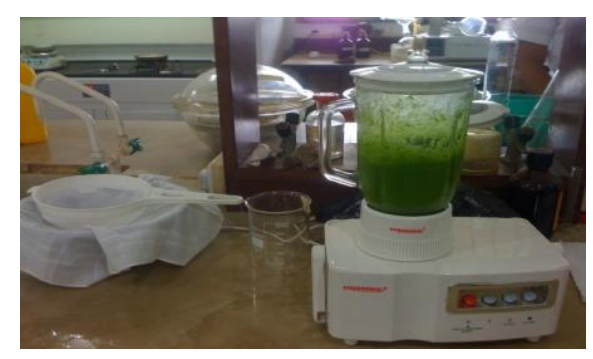

Fig2.1. Chorophyll extraction setup

\subsubsection{Extraction with $n$-hexane}

$10 \mathrm{~g}$ of fresh bitter leaf was put in $200 \mathrm{ml}$ of $\mathrm{n}$-hexane in a blender and blended to crush the plant cell for three (3) minutes and sieved using sieves of three (3) different pore sizes. The filtrate was taken for 
initial scan in the UV/visible wavelength range $(200-800 \mathrm{~nm})$ using UV/visible spectrophotometer. Absorbance of filtrate was also measured at $430 \mathrm{~nm}$ and $660 \mathrm{~nm}$. The filtrate was stored at room temperature and at water activity of 0.33 and 0.75 . The UV/visible scan and absorbance measurements were carried out immediately after extraction and repeated weekly for four (4) weeks (one month) for samples stored at room temperature and repeated at the end of one month for samples stored at 0.33 and 0.75 water activity. The same procedure was repeated for pawpaw leaf and pumpkin leaf.

\subsubsection{Extraction with Petroleum Ether}

$10 \mathrm{~g}$ of fresh bitter leaf was put in $200 \mathrm{ml}$ of petroleum ether in a blender and blended to crush the plant cell for three (3) minutes and sieved using sieves of three (3) different pore sizes. The filtrate was taken for initial scan in the UV/visible wavelength range $(200-800 \mathrm{~nm})$ using UV/visible spectrophotometer. Absorbance of filtrate was also measured at $430 \mathrm{~nm}$ and $660 \mathrm{~nm}$. The filtrate was stored at room temperature and at water activity of 0.33 and 0.75 . The UV/visible scan and absorbance measurements were carried out immediately after extraction and repeated weekly for four (4) weeks (one month) for samples stored at room temperature and repeated at the end of one month for samples stored at 0.33 and 0.75 water activity. The same procedure was repeated for pawpaw leaf and pumpkin leaf.

\subsubsection{Extraction with Acetone}

$10 \mathrm{~g}$ of fresh bitter leaf was put in $200 \mathrm{ml}$ of acetone in a blender and blended to crush the plant cell for three (3) minutes and sieved using sieves of three (3) different pore sizes. The filtrate was taken for initial scan in the UV/visible wavelength range $(200-800 \mathrm{~nm})$ using UV/visible spectrophotometer. Absorbance of filtrate was also measured at $430 \mathrm{~nm}$ and $660 \mathrm{~nm}$. The filtrate was stored at room temperature and at water activity of 0.33 and 0.75 . The UV/visible scan and absorbance measurements were carried out immediately after extraction and repeated weekly for four (4) weeks (one month) for samples stored at room temperature and repeated at the end of one month for samples stored at 0.33 and 0.75 water activity. The same procedure was repeated for pawpaw leaf and pumpkin leaf.

\subsubsection{Extraction with Ethanol}

$10 \mathrm{~g}$ of fresh bitter leaf was put in $200 \mathrm{ml}$ of ethanol in a blender and blended to crush the plant cell for three (3) minutes and sieved using sieves of three (3) different pore sizes. The filtrate was taken for initial scan in the UV/visible wavelength range $(200-800 \mathrm{~nm})$ using UV/visible spectrophotometer. Absorbance of filtrate was also measured at $430 \mathrm{~nm}$ and $660 \mathrm{~nm}$. The filtrate was stored at room temperature and at water activity of 0.33 and 0.75 . The UV/visible scan and absorbance measurements were carried out immediately after extraction and repeated weekly for four (4) weeks (one month) for samples stored at room temperature and repeated at the end of one month for samples stored at 0.33 and 0.75 water activity. The same procedure was repeated for pawpaw leaf and pumpkin leaf.

\subsection{Preparation of magnesium chloride stock solution}

$600 \mathrm{~g}$ of magnesium chloride was weighed into $200 \mathrm{ml}$ of distilled water, the solution was thoroughly stirred until no more solute dissolved in the solvent

\subsection{Preparation of sodium chloride stock solution}

$300 \mathrm{~g}$ of sodium chloride was weighed into $200 \mathrm{ml}$ of distilled water, the solution was thoroughly stirred until no more solute dissolved in the solvent.

\subsection{Sample Storage}

To store samples at room temperature, extracts were poured into beakers and kept in the laboratory at room temperature. To store samples at water activity of 0.33 and 0.75 , Stock solutions of $\mathrm{NaCl}$ and $\mathrm{MgCl}$ were poured into 2 separate desiccators, and extract from the chlorophyll in beakers were placed in the desiccator. The desiccator was covered for one month

\subsection{Absorbance measurement}

Two clean spectrophotometer cuvettes were obtained. At least $3 \mathrm{ml}$ of the solvent used for extraction were placed in one cuvette and $2 \mathrm{ml}$ of plant extract plus $1 \mathrm{ml}$ of solvent was placed in the other cuvette 
Chlorophyll Extraction and Storage Studies on Selected Vegetables (Bitter Leaf - Vernonia Amygdalina, Pawpaw Leaf - Carica Papaya and Pumpkin Leaf - Telfairia Occidentalis)

(dilution of extract in the ratio of 2:1 was to avoid over range due to high concentration of extract). The spectrophotometer was set at a wavelength of 430nm using the solvent cuvette. Measurement of absorbance was taken at $430 \mathrm{~nm}$.

\subsection{Objective of this research}

Chlorophyll is the green pigment responsible for the color of leaves and green pigments found in cyanobacteria and the chloroplasts of algae. Chlorophyll is an extremely important biomolecule, which allows plants to absorb energy from sunlight. Its presence in leaves is crucial for photosynthesis. Bitter leaf, pawpaw leaf and pumpkin leaf are commonly known for their high nutritional and medicinal value and are widely consumed as vegetables across Africa. Much research has been done on chlorophyll extraction and storage. However, only a few researches have been done on effect of extraction solvent and storage on chlorophyll extracted from bitter leaf, pawpaw leaf and pumpkin leaf. This research assesses the effect of extraction solvents, studies the changes/stability of chlorophyll extracts at varied conditions and compares the effect of storage conditions at room temperature and at different water activities by studying the absorbance pattern of the chlorophyll extract.

\subsection{Quality Assurance}

Special precautions taken for quality assurance were as follows; all chemicals and reagents used are of analytical grade and all samples were attemperated to $20^{\circ}$ before being analysed. Also, all glassware used for this research are properly washed and soaked overnight in chromic acid.

\section{RESUltS AND DISCUSSION}

Table3.0. Absorbance values at 430nm for bitter leaf extracts stored at room temperature.

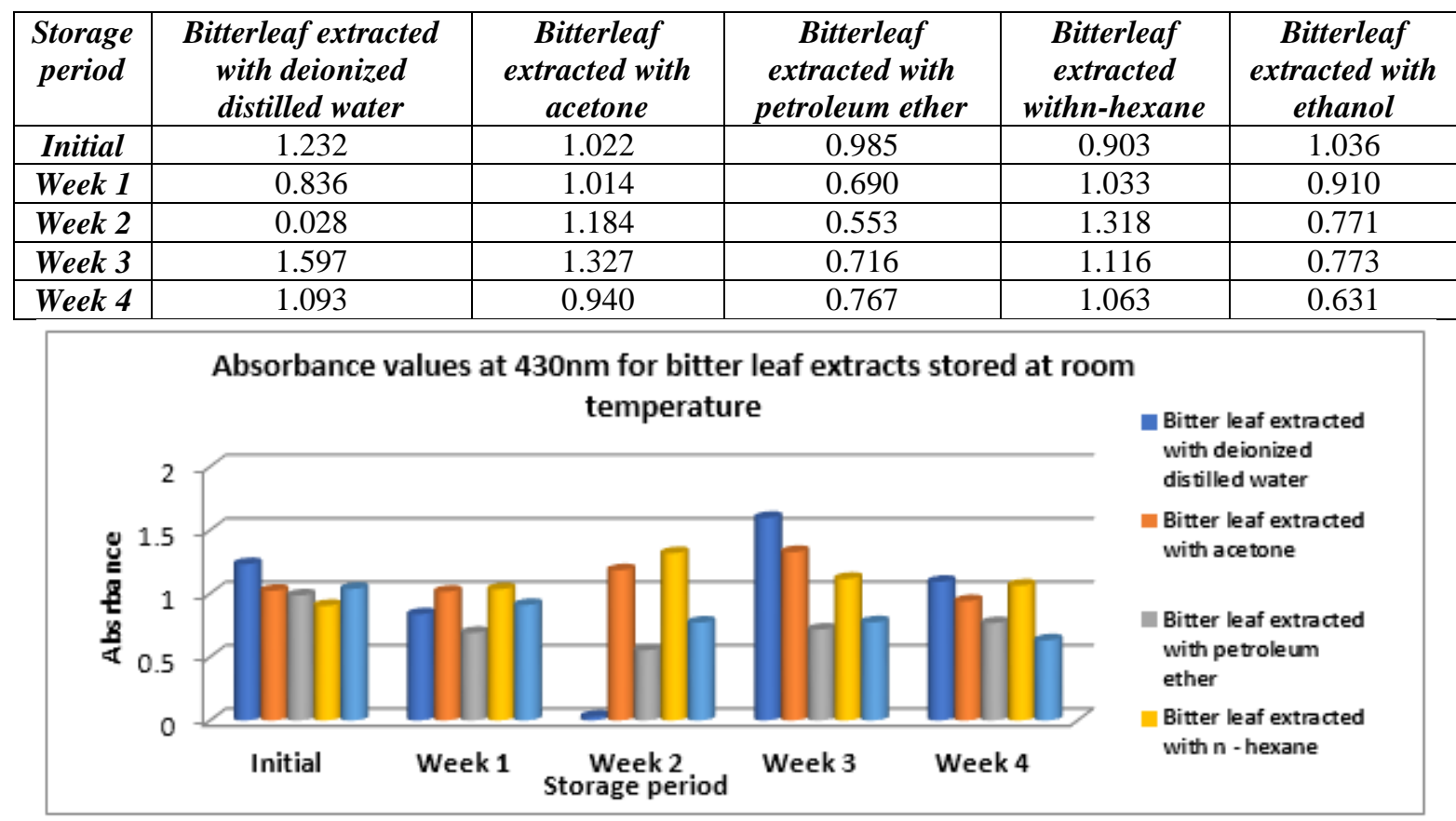

Fig3.0. Absorbance values at 430nm for bitter leaf extracts stored at room temperature

Table3.1. Absorbance values at 430nm for pawpaw leaf extracts stored at room temperature

\begin{tabular}{|c|c|c|c|c|c|}
\hline $\begin{array}{c}\text { Storage } \\
\text { period }\end{array}$ & $\begin{array}{c}\text { Pawpaw leaf } \\
\text { extracted with } \\
\text { deionized distilled } \\
\text { water }\end{array}$ & $\begin{array}{c}\text { Pawpaw leaf } \\
\text { extracted with } \\
\text { acetone }\end{array}$ & $\begin{array}{c}\text { Pawpaw leaf } \\
\text { extracted } \\
\text { petroleum ether }\end{array}$ & $\begin{array}{c}\text { Pawpaw leaf } \\
\text { extracted with } \\
\text { n-hexane }\end{array}$ & $\begin{array}{c}\text { Pawpaw leaf } \\
\text { extracted } \\
\text { with ethanol }\end{array}$ \\
\hline Initial & 1.106 & 1.062 & 0.908 & 0.886 & 1.093 \\
\hline Week 1 & 0.720 & 1.197 & 0.988 & 1.538 & 1.657 \\
\hline Week 2 & 0.022 & 1.367 & 1.126 & 1.825 & 1.009 \\
\hline Week 3 & 1.773 & 1.537 & 1.296 & 1.595 & 0.674 \\
\hline Week 4 & 1.637 & 1.289 & 1.331 & 1.576 & 0.020 \\
\hline
\end{tabular}


Chlorophyll Extraction and Storage Studies on Selected Vegetables (Bitter Leaf - Vernonia Amygdalina, Pawpaw Leaf - Carica Papaya and Pumpkin Leaf - Telfairia Occidentalis)

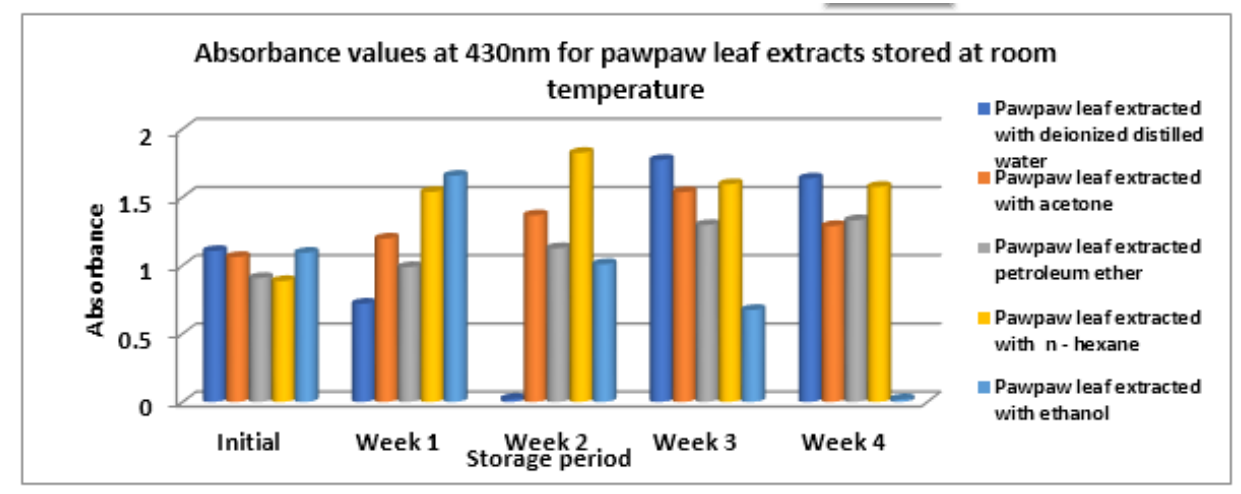

Fig3.1. Absorbance values at 430nm for pawpaw leaf extracts stored at room temperature

Table3.2. Absorbance values at 430nm for pumpkin leaf extract stored at room temperature

\begin{tabular}{|c|c|c|c|c|c|}
\hline $\begin{array}{c}\text { Storage } \\
\text { period }\end{array}$ & $\begin{array}{c}\text { Pumpkin leaf } \\
\text { extracted with } \\
\text { Deionized } \\
\text { distilled water }\end{array}$ & $\begin{array}{c}\text { Pumpkin leaf } \\
\text { extracted with } \\
\text { acetone }\end{array}$ & $\begin{array}{c}\text { Pumpkin leaf } \\
\text { extracted } \\
\text { petroleum } \\
\text { ether }\end{array}$ & $\begin{array}{c}\text { Pumpkin leaf } \\
\text { extracted with } \\
\text { n-hexane }\end{array}$ & $\begin{array}{c}\text { Pumpkin leaf } \\
\text { extracted with } \\
\text { ethanol }\end{array}$ \\
\hline Initial & 1.808 & 1.286 & 1.451 & 0.919 & 1.608 \\
\hline Week 1 & 1.570 & 1.258 & 1.432 & 0.698 & 1.836 \\
\hline Week 2 & 1.332 & 1.229 & 1.259 & 0.694 & 0.872 \\
\hline Week 3 & 1.327 & 1.063 & 1.257 & 0.593 & 0.744 \\
\hline Week 4 & 1.286 & 0.961 & 1.080 & 0.557 & 0.500 \\
\hline
\end{tabular}

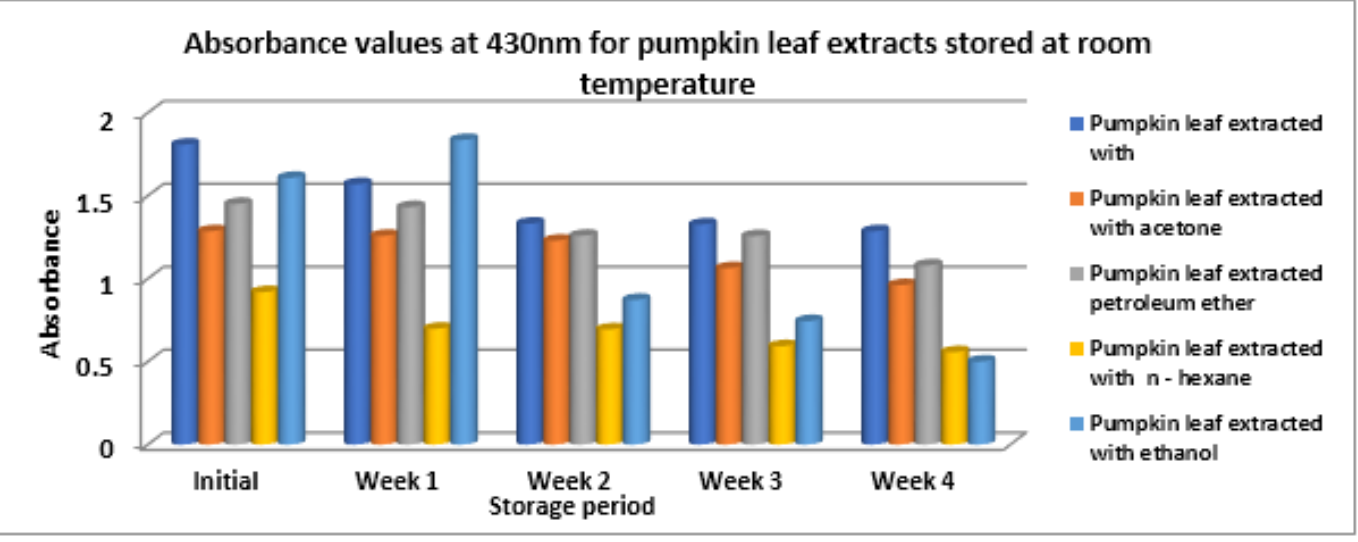

Fig3.2. Absorbance values at 430nm for pumpkin leaf extracts stored at room temperature

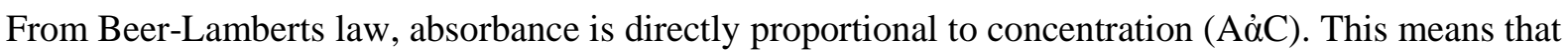
a high or low absorbance value is as a result of high or low concentration. With respect to absorbance values at $430 \mathrm{~nm}$ for bitter leaf extracted with 5 different solvents and stored at room temperature, it was observed that, initially after extraction, deionized distilled water extracts had the highest absorbance value of 1.232 (Table 3.0), followed by ethanol extracts, acetone extracts, petroleum ether extract and n-hexane extracts had the lowest absorbance of 0.903 (Table 3.0). This may be because of the order of polarity of the solvents used for extraction. The order of polarity was deionized distilled water $>$ ethanol $>$ acetone $>$ petroleum ether $>$ n-hexane.

In other words, the higher the polarity of the solvent, the higher was its extraction ability, hence the darker the shade of the green colour of the extracts obtained and the higher the absorbance of the extract. Since like dissolves like, more of the hydrophyllic chlorophyll a and chlorophyllide a portion of chlorophyll was dissolved by polar solvents and more of the hydrophobic phytol portion of chlorophyll was dissolved by non-polar solvents. This may have limited the extraction of the chlorophyll a and chloropyllide a portion by non-polar solvents. Similarly, for absorbance at 430nm for pawpawleaf extracts (Table 3.1) and pumpkin leaf extracts (Table 3.2), initially after extraction a similar trend was observed and hence, a similar explanation is indicated

However, on the $4^{\text {th }}$ week of storage, it was observed that deionized distilled water extract, had the highest absorbance values. This shows that the rate of degradation of chlorophyll a was slower in 
Chlorophyll Extraction and Storage Studies on Selected Vegetables (Bitter Leaf - Vernonia Amygdalina, Pawpaw Leaf - Carica Papaya and Pumpkin Leaf - Telfairia Occidentalis)

deionized distilled water extracts, ethanol extract had the least absorbance value. This shows that the degradation of chlorophyll a was faster in ethanol extracts. The increase and decrease in absorbance values throughout the storage period of 4 weeks for all extracts may be as a result of the conversion of chlorophyll $\mathrm{b}$ to chlorophyll a and degradation of chlorophyll a, respectively.

Table3.3. Absorbance values at $660 \mathrm{~nm}$ for bitter leaf extract stored at room temperature

\begin{tabular}{|c|c|c|c|c|c|}
\hline Storage period & $\begin{array}{c}\text { Bitterleaf } \\
\text { extracted with } \\
\text { deionized } \\
\text { distilled water }\end{array}$ & $\begin{array}{c}\text { Bitterleaf } \\
\text { extracted with } \\
\text { acetone }\end{array}$ & $\begin{array}{c}\text { Bitterleaf } \\
\text { extractedwith } \\
\text { petroleum } \text { ether }\end{array}$ & $\begin{array}{c}\text { Bitterleaf } \\
\text { extracted with } \\
\text { n-hexane }\end{array}$ & $\begin{array}{c}\text { Bitterleaf } \\
\text { extracted with } \\
\text { Ethanol }\end{array}$ \\
\hline Initial & 1.348 & 0.410 & 0.288 & 0.257 & 0.519 \\
\hline Week 1 & 1.020 & 0.884 & 0.296 & 0.122 & 0.843 \\
\hline Week 2 & 1.001 & 1.069 & 0.456 & 0.410 & 0.755 \\
\hline Week 3 & 1.993 & 1.254 & 0.606 & 0.362 & 1.791 \\
\hline Week 4 & 1.641 & 1.044 & 0.681 & 0.226 & 1.911 \\
\hline
\end{tabular}

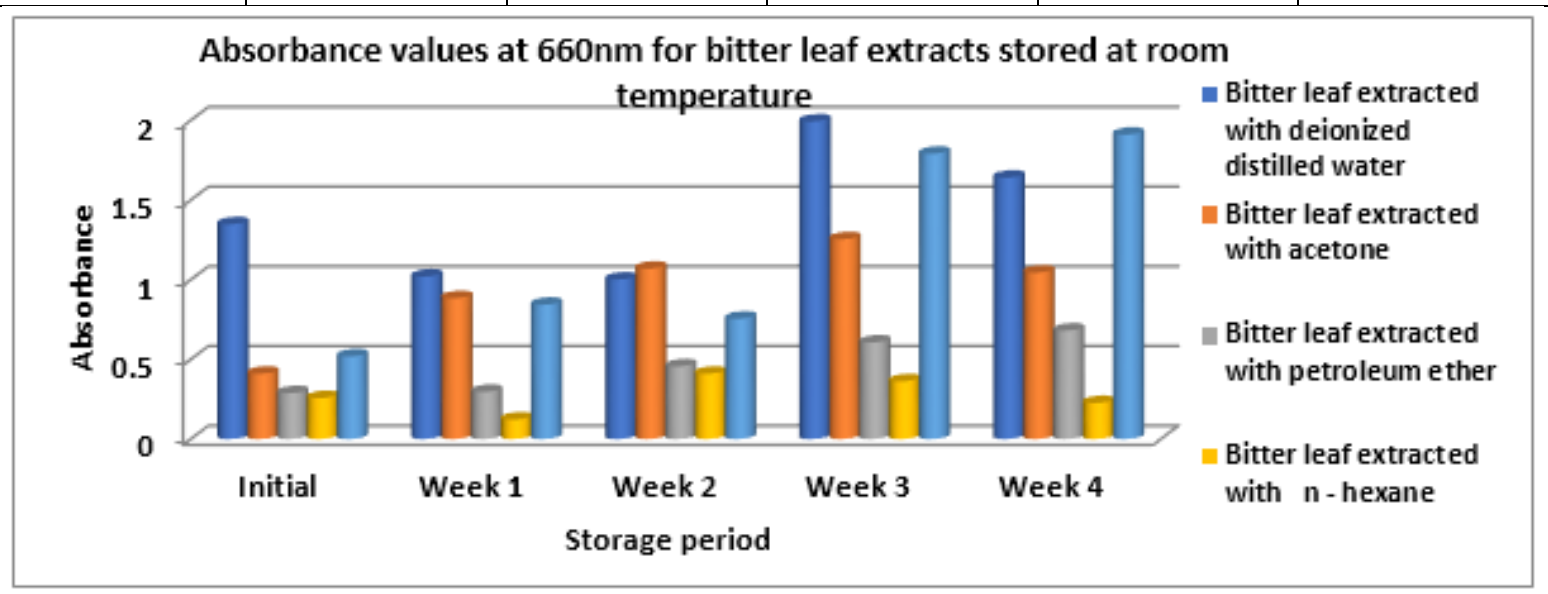

Fig3.3. Absorbance values at 660nm for bitter leaf extracts stored at room temperature

Table3.4. Absorbance values at 660nm for pawpaw leaf extract stored at room temperature

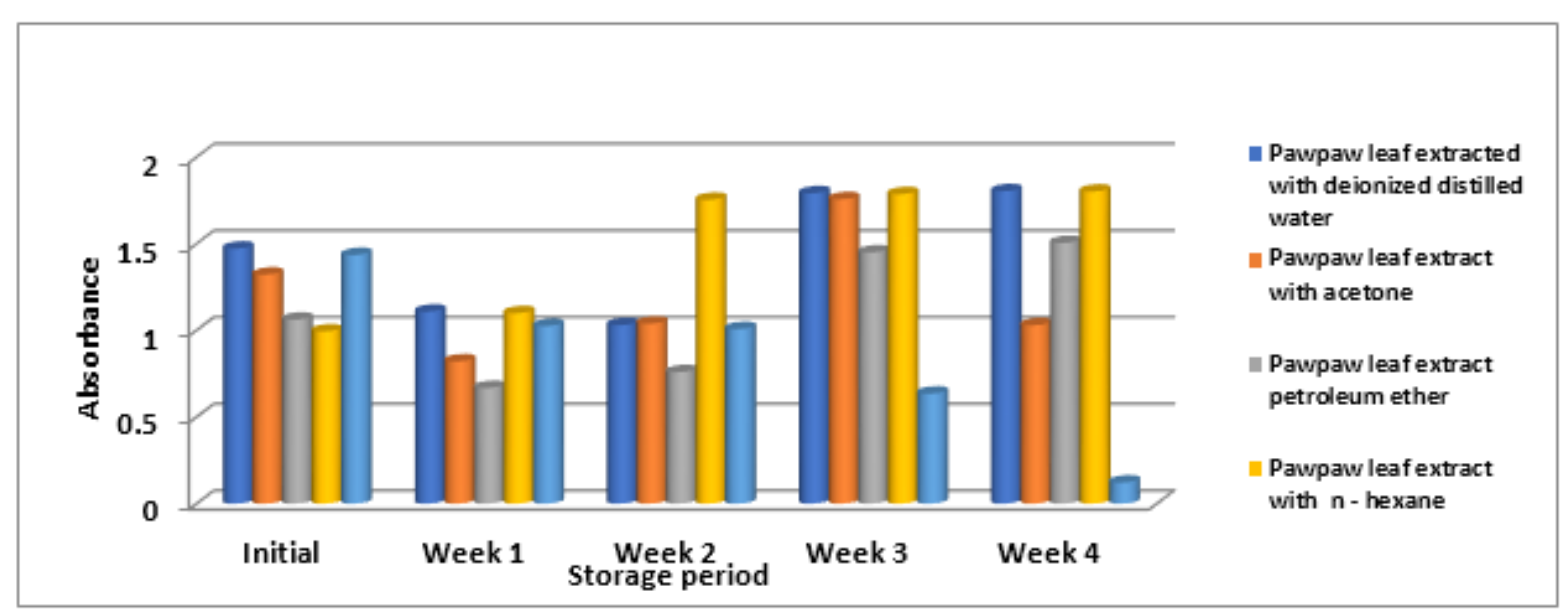

Fig3.4. Absorbance values at 660nm for pawpaw leaf extracts stored at room temperature

Table3.5. Absorbance value at $660 \mathrm{~nm}$ for pumpkin leaf extract stored at room temperature

\begin{tabular}{|c|c|c|c|c|c|}
\hline $\begin{array}{c}\text { Storage } \\
\text { period }\end{array}$ & $\begin{array}{c}\text { Pumpkin leaf } \\
\text { extracted with } \\
\text { deionized } \\
\text { distilled water }\end{array}$ & $\begin{array}{c}\text { Pumpkin leaf } \\
\text { extracted with } \\
\text { acetone }\end{array}$ & $\begin{array}{c}\text { Pumpkin leaf } \\
\text { extracted with } \\
\text { petroleum } \\
\text { ether }\end{array}$ & $\begin{array}{c}\text { Pumpkin leaf } \\
\text { extracted with } \\
\text { n-hexane }\end{array}$ & $\begin{array}{c}\text { Pumpkin leaf } \\
\text { extracted with } \\
\text { ethanol }\end{array}$ \\
\hline Initial & 1.795 & 1.551 & 1.029 & 0.800 & 1.655 \\
\hline Week 1 & 1.509 & 1.395 & 1.983 & 0.764 & 1.525 \\
\hline Week 2 & 1.223 & 1.239 & 1.422 & 0.610 & 0.830 \\
\hline Week 3 & 1.174 & 1.072 & 1.303 & 0.515 & 0.747 \\
\hline Week 4 & 1.154 & 1.022 & 1.224 & 0.428 & 0.538 \\
\hline
\end{tabular}


Chlorophyll Extraction and Storage Studies on Selected Vegetables (Bitter Leaf - Vernonia Amygdalina, Pawpaw Leaf - Carica Papaya and Pumpkin Leaf - Telfairia Occidentalis)

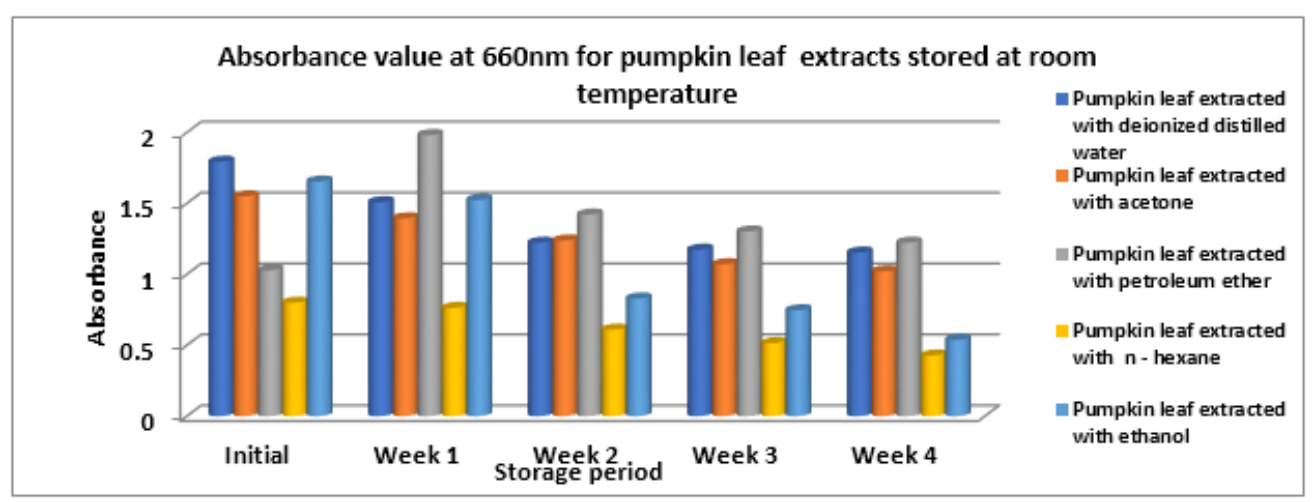

Fig3.5. Absorbance value at $660 \mathrm{~nm}$ for pumpkin leaf extracts stored at room temperature

With respect to absorbance values at $660 \mathrm{~nm}$ for bitter leaf extracted with 5 different solvents and stored at room temperature, it was observed that, initially after extraction, deionized distilled water extracts had the highest absorbance value of 1.232 (Table 3.3), followed by ethanol extracts, acetone extracts, petroleum ether extract and n-hexane extracts had the lowest absorbance of 0.903 (Table 3.3). This may be because of the order of polarity of the solvents used for extraction. The order of polarity was deionized distilled water $>$ ethanol $>$ acetone $>$ petroleum ether $>n$-hexane. The formation of pheophytin a in extracts was initiated by the release of cellular acid during extraction and synthesis of new acids.

Similarly, for absorbance at 660nm for pawpawleaf extracts (Table 3.4) and pumpkin leaf extracts (Table 3.5), initially after extraction a similar trend was observed and hence, a similar explanation is indicated. However, on the $4^{\text {th }}$ week of storage, it was observed that deionized distilled water extracts of bitter leaf and pawpaw leaf, had the highest absorbance values of 1.641 and 1.822 (Table 3.3 and Table 3.4) respectively, which shows that the rate of degradation of chlorophyll a to pheophytin a was fast and degradation of pheophytin a was slow. Ethanol extract of pawpaw leaf had the lowest absorbance value of 0.122 (Table 3.4), this shows that the degradation of chlorophyll a was faster in ethanol extract of pawpaw leaf. For n-hexane extracts of pawpaw leaf (Table 3.4) and pumpkin leaf (Table 3.5), decrease in absorbance values was observed during storage which showed that only degradation of pheophytin a occurred. There was little or no degradation of chlorophyll a to pheophytin a. The increase and decrease in absorbance values throughout the storage period for all extracts may be as a result of the degradation of chlorophyll a to pheophytin a and the degradation of pheophytin a to pheophorbide due to the action of chloropyllase and Mg-dechelation. In a study by Kaewsuksaeng et al., (2006) on the effect of storage on Mg-dechelation activity and the formation of chlorophyll derivatives, chlorophyll $a$ and pheophytin $a$ decreased concomitantly with the enhancement of pheophorbide.

Table3.6. Absorption maximum for bitter leaf extracted with deionized distilled water stored at room temperature

\begin{tabular}{|c|c|c|}
\hline Storage Period & Wavelength of maximum absorption(nm) & Absorbance \\
\hline Initial & 670 & 2.312 \\
\hline Week 1 & 670 & 0.316 \\
\hline Week 2 & 670 & 2.275 \\
\hline Week 3 & 670 & 2.232 \\
\hline Week 4 & 672 & 2.003 \\
\hline
\end{tabular}

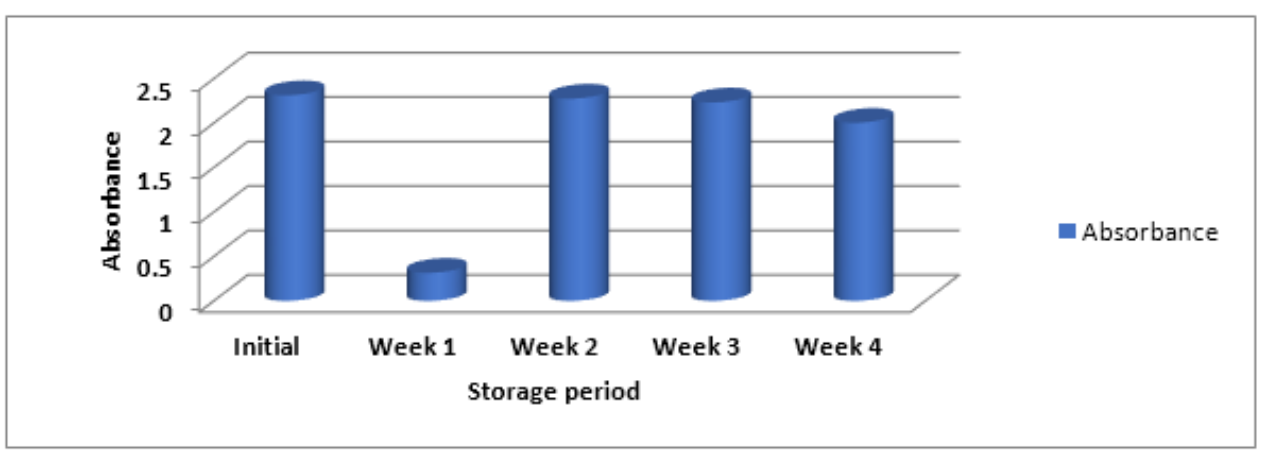

Fig3.6. Absorption maximum for bitter leaf extracted with deionized distilled water stored at room temperature 
Chlorophyll Extraction and Storage Studies on Selected Vegetables (Bitter Leaf - Vernonia Amygdalina, Pawpaw Leaf - Carica Papaya and Pumpkin Leaf - Telfairia Occidentalis)

Table3.7. Absorption maximum for bitter leaf extracted with acetone stored at room temperature

\begin{tabular}{|c|c|c|}
\hline Storage Period & Wavelength of maximum absorption $(\mathbf{n m})$ & Absorbance \\
\hline Initial & 670 & 2.127 \\
\hline Week 1 & 670 & 2.215 \\
\hline Week 2 & 671 & 2.222 \\
\hline Week 3 & 670 & 2.172 \\
\hline Week 4 & 670 & 2.238 \\
\hline
\end{tabular}

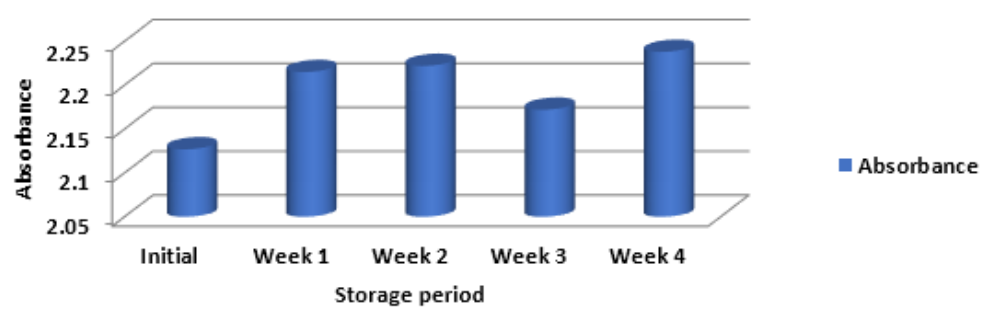

Fig3.7. Absorption maximum for bitter leaf extracted with acetone stored at room temperature

Table3.8. Absorption maximum for bitter leaf extracted with ethanol stored at room temperature

\begin{tabular}{|c|c|c|}
\hline Storage Period & Wavelength of maximum absorption $\mathbf{( n m )}$ & Absorbance \\
\hline Initial & 670 & 2.158 \\
\hline Week 1 & 671 & 2.156 \\
\hline Week 2 & 670 & 2.232 \\
\hline Week 3 & 670 & 2.140 \\
\hline Week 4 & 672 & 2.123 \\
\hline
\end{tabular}

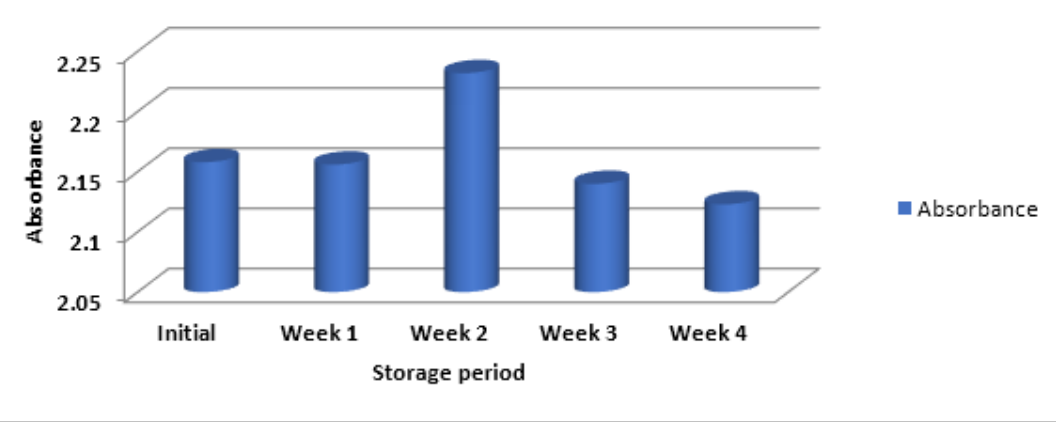

Fig3.8. Absorption maximum for bitter leaf extracted with ethanol stored at room temperature

Table3.9. Absorption maximum for pawpaw leaf extracted with deionized distilled water stored at room temperature

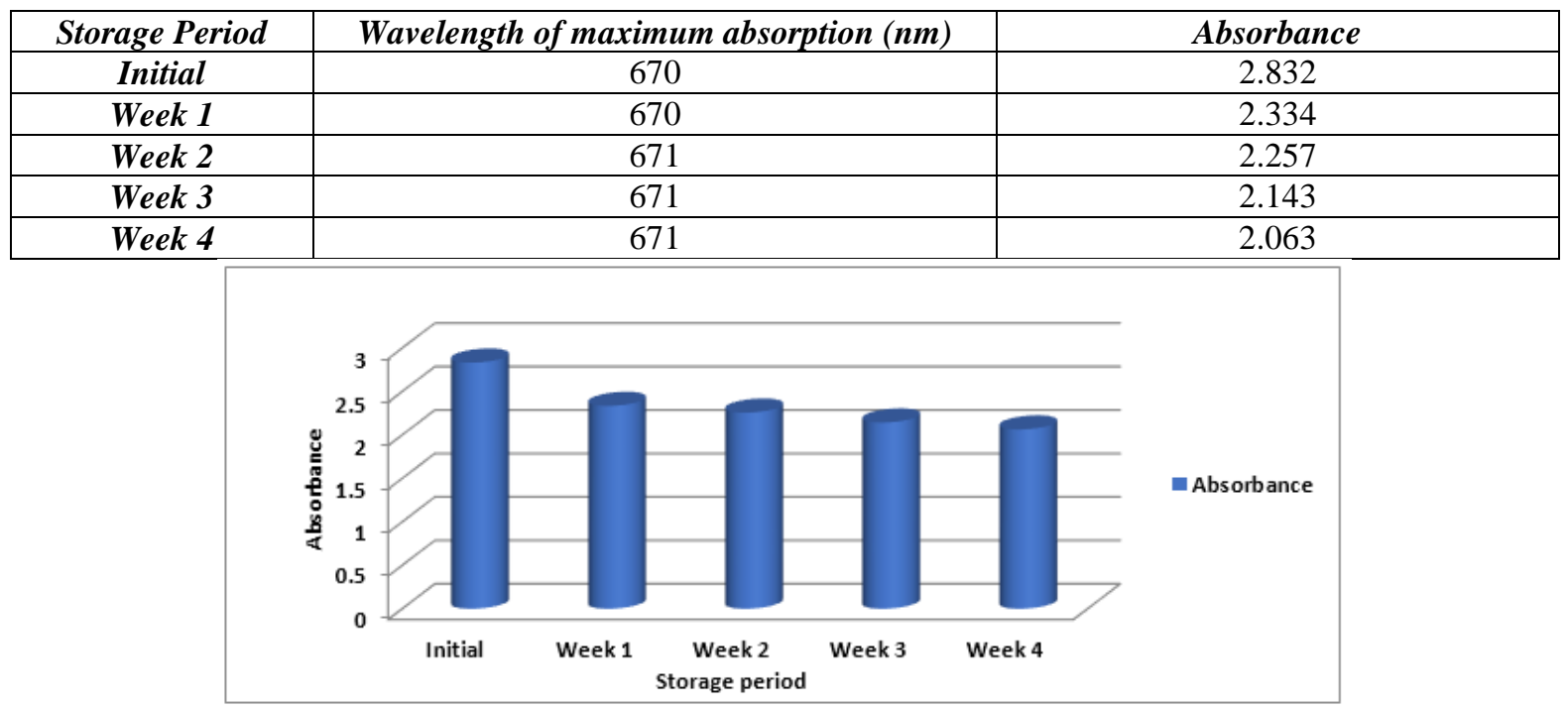

Fig3.9. Absorption maximum for pawpaw leaf extracted with deionized distilled water stored at room temperature 
Chlorophyll Extraction and Storage Studies on Selected Vegetables (Bitter Leaf - Vernonia Amygdalina, Pawpaw Leaf - Carica Papaya and Pumpkin Leaf - Telfairia Occidentalis)

Table3.10. Absorption maximum for pawpaw leaf extracted with acetone stored at room temperature

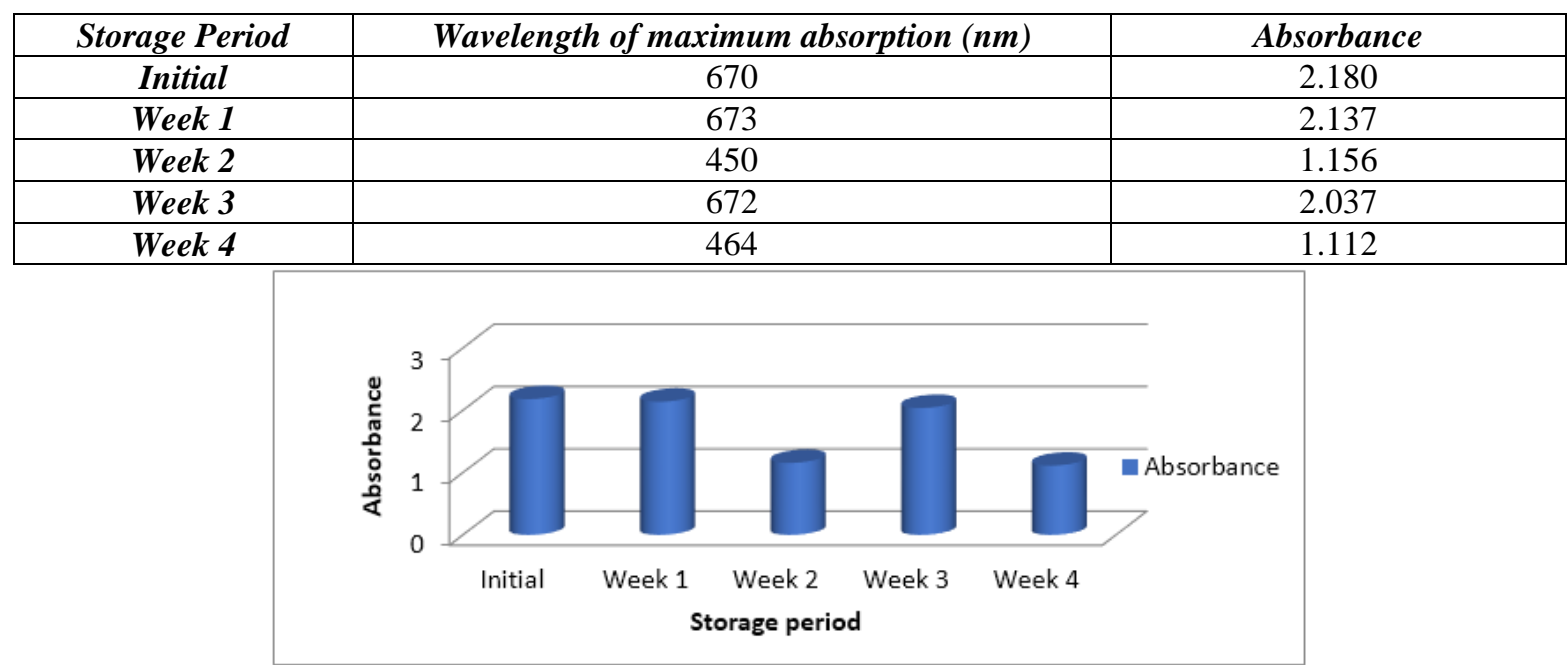

Fig3.10. Absorption maximum for pawpaw leaf extracted with acetone stored at room temperature

Table3.11. Absorption maximum for pawpaw leaf extracted with petroleum ether stored at room temperature

\begin{tabular}{|c|c|c|}
\hline Storage Period & Wavelength of maximum absorption (nm) & Absorbance \\
\hline Initial & 668 & 1.900 \\
\hline Week 1 & 670 & 2.182 \\
\hline Week 2 & 670 & 0.227 \\
\hline Week 3 & 670 & 2.213 \\
\hline Week 4 & 670 & 2.228 \\
\hline
\end{tabular}

Table3.11. Absorption maximum for pawpaw leaf extracted with petroleum ether stored at room temperature

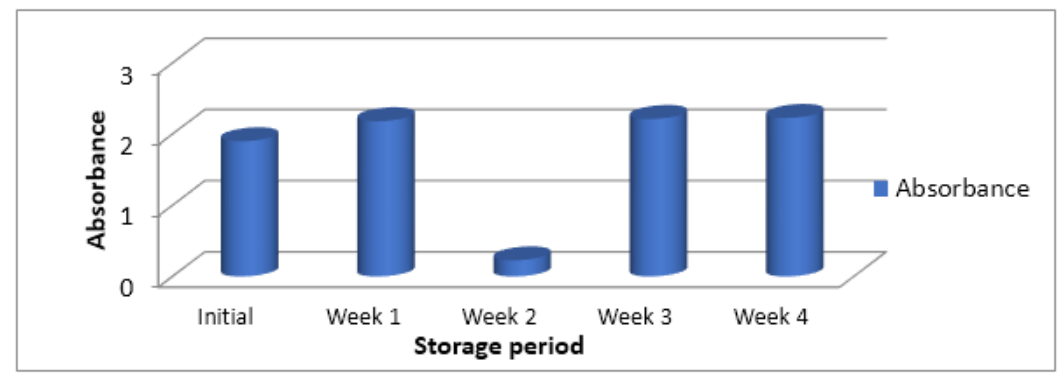

Fig3.11. Absorption maximum for pawpaw leaf extracted with petroleum ether stored at room temperature

Table3.12. Absorption maximum for pawpaw leaf extracted with n-hexane stored at room temperature

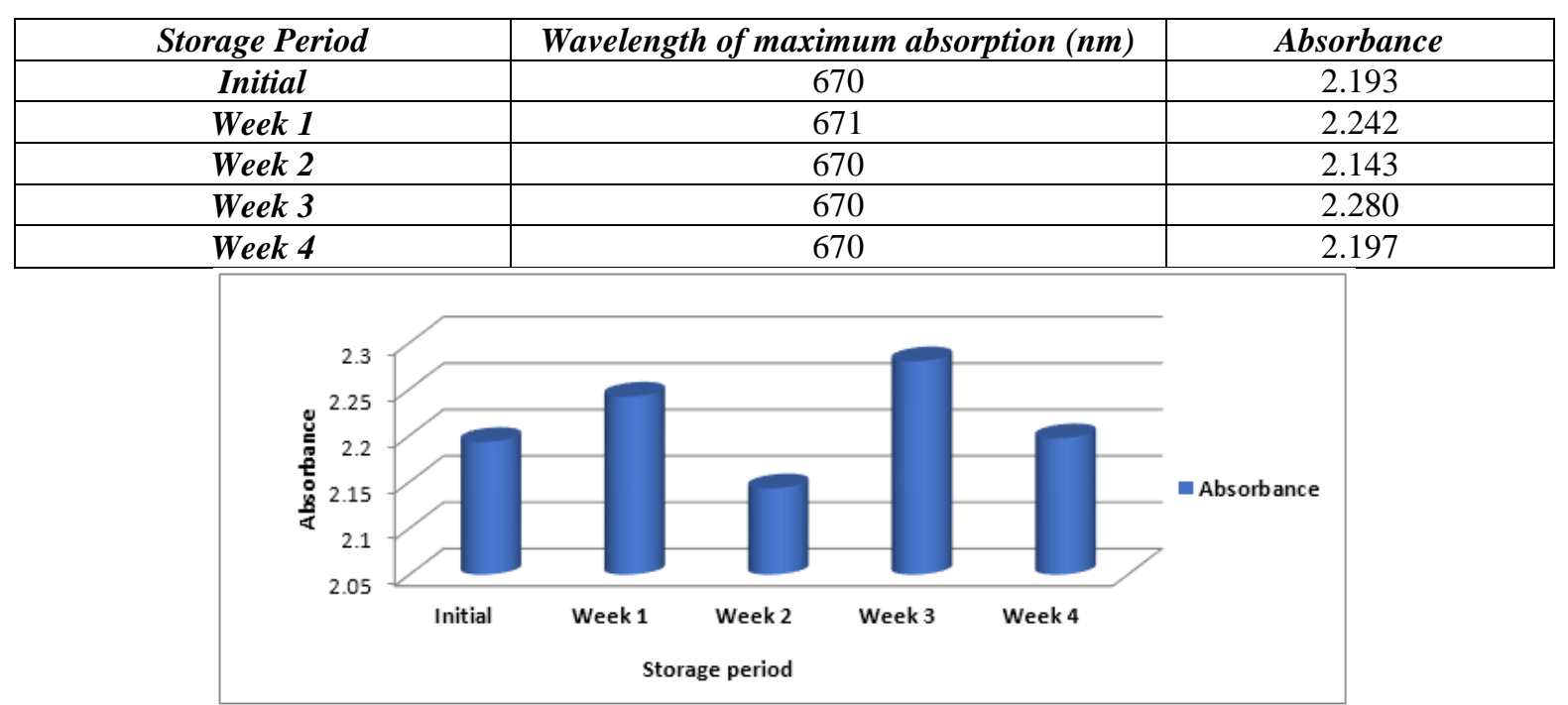

Fig3.12. Absorption maximum for pawpaw leaf extracted with n-hexane stored at room temperature 
Chlorophyll Extraction and Storage Studies on Selected Vegetables (Bitter Leaf - Vernonia Amygdalina, Pawpaw Leaf - Carica Papaya and Pumpkin Leaf - Telfairia Occidentalis)

Table3.13. Absorption maximum for pawpaw leaf extracted with ethanol stored at room temperature

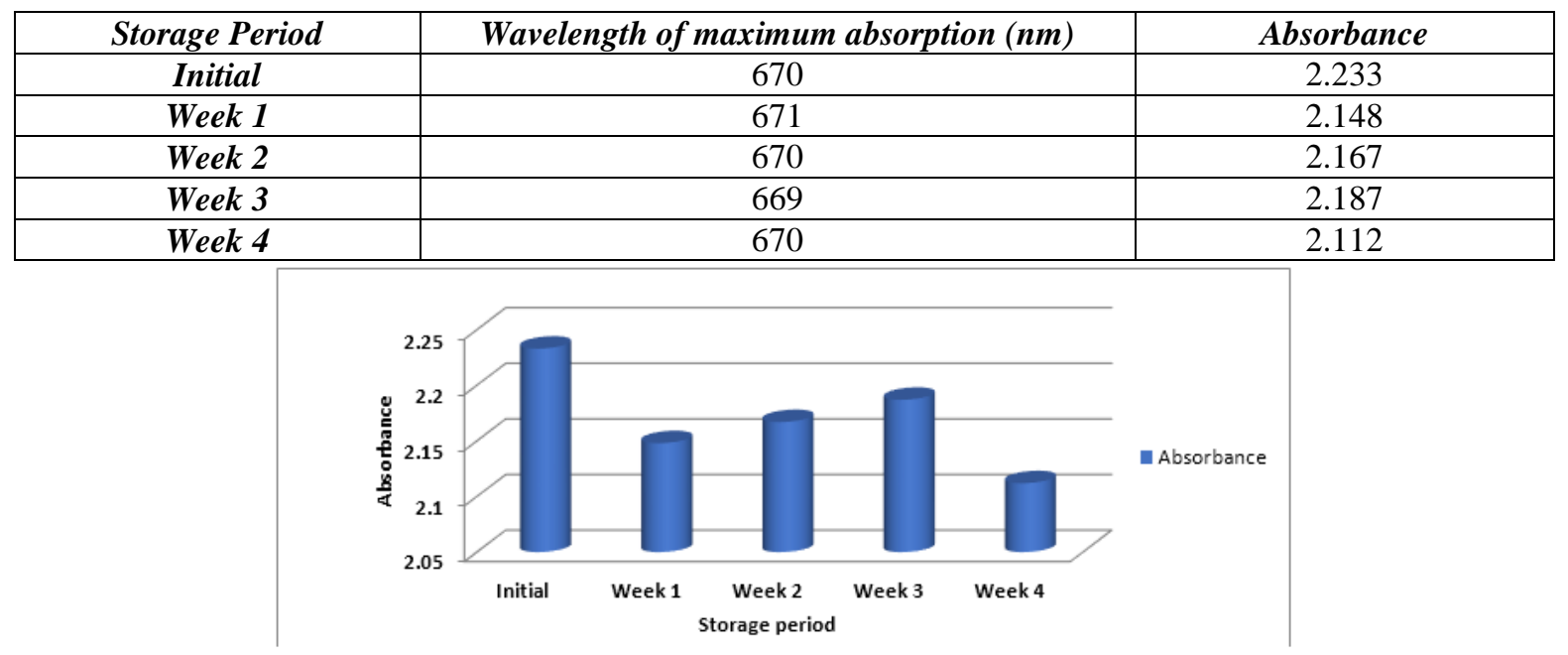

Fig3.13. Absorption maximum for pawpaw leaf extracted with ethanol stored at room temperature

Table3.14. Absorption maximum for pumpkin leaf extracted with deionized distilled water stored at room temperature

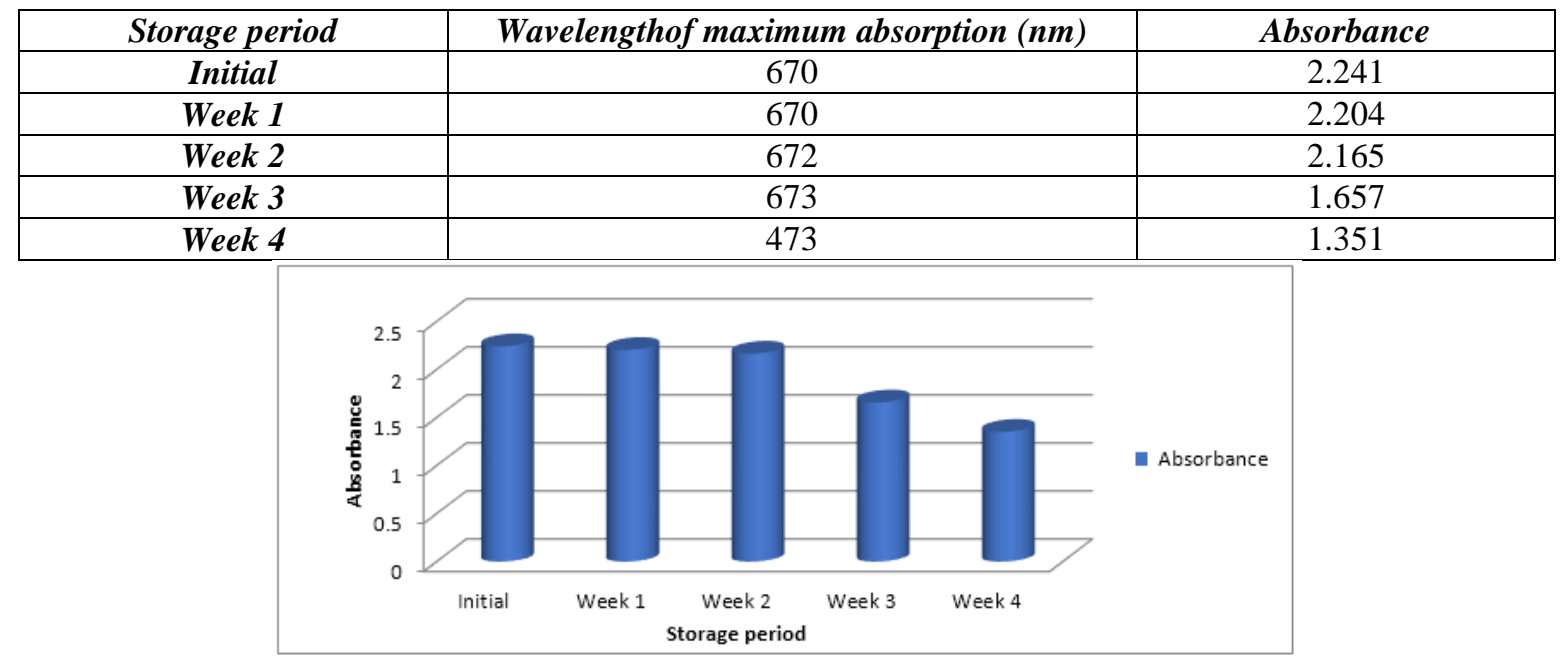

Fig3.14. Absorption maximum for pumpkin leaf extracted with deionized distilled water stored at room temperature

Table3.15. Absorption maximum for pumpkin leaf extracted with acetone stored at room temperature

\begin{tabular}{|c|c|c|}
\hline Storage period & Wavelengthof maximum absorption (nm) & Absorbance \\
\hline Initial & 671 & 2.110 \\
\hline Week 1 & 678 & 2.009 \\
\hline Week 2 & 671 & 2.045 \\
\hline Week 3 & 670 & 2.208 \\
\hline Week 4 & 654 & 2.180 \\
\hline
\end{tabular}

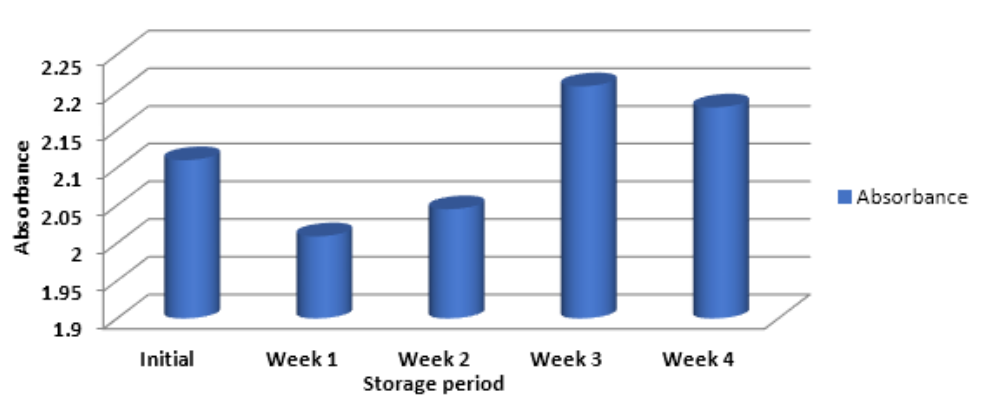

Fig3.15. Absorption maximum for pumpkin leaf extracted with acetone stored at room temperature 
Chlorophyll Extraction and Storage Studies on Selected Vegetables (Bitter Leaf - Vernonia Amygdalina, Pawpaw Leaf - Carica Papaya and Pumpkin Leaf - Telfairia Occidentalis)

Table3.16. Absorption maximum for pumpkin leaf extracted with petroleum ether stored at room temperature

\begin{tabular}{|c|c|c|c|}
\hline \multicolumn{2}{|c|}{ Storage period } & Wavelengthof maximum absorption (nm) & Absorbance \\
\hline Initial & 668 & 1.851 \\
\hline Week 1 & 670 & 2.062 \\
\hline Week 2 & 671 & 1.973 \\
\hline Week 3 & 671 & \\
\hline \\
\hline
\end{tabular}

Fig3.16. Absorption maximum for pumpkin leaf extracted with petroleum ether stored at room temperature

Table3.17. Absorption maximum for pumpkin leaf extracted with ethanol stored at room temperature

\begin{tabular}{|c|c|c|}
\hline Storage Period & Wavelength of maximum absorption (nm) & Absorbance \\
\hline Initial & 670 & 2.163 \\
\hline Week 1 & 671 & 2.090 \\
\hline Week 2 & 670 & 2.123 \\
\hline Week 3 & 669 & 2.062 \\
\hline Week 4 & 668 & \\
\hline \\
\hline
\end{tabular}

Fig3.17. Absorption maximum for pumpkin leaf extracted with ethanol stored at room temperature

The wavelength of maximum absorption for extracts in tables above was 670nm (Tables 3.6 -3.17), the peak of maximum absorption at $670 \mathrm{~nm}$ may be due to the dominant presence of chlorophyll a in the extracts. In a similar study by Atwell et al (1999), absorption maximum for crude chlorophyll extracts from plants well exposed to sunlight showed predominantly chlorophyll a with maximum absorption at 437nm and 672nm (Table 3.6) and pumpkin leaf (Table 3.9), ethanol extracts of bitter leaf (Table 3.8), paw paw leaf (Table 3.13) and pumpkin leaf (Table 3.16), petroleum ether extracts of pawpaw leaf (Table 3.11) and pumpkin leaf (Table 3.16), acetone extract of bitter leaf (Table 3.17) and n-hexane extract of pawpaw leaf, this may also be due to the dominant presence of chlorophyll a which may have resulted from the conversion of chlorophyll $b$ to chlorophyll a on storage. However, on the $4^{\text {th }}$ week of storage, for pawpaw leaf extracted with acetone (Table 3.10), pumpkin leaf extracted with deionized distilled water (Table 3.14) and acetone (Table 3.15), maximum absorption decreased to 464nm, 473nm and $654 \mathrm{~nm}$ respectively, this may be due to chlorophyll b or other pigments. Absorption of chlorophyll $\mathrm{b}$ at $472 \mathrm{~nm}$ and $653 \mathrm{~nm}$ in chlorophyll solution was also reported by Evans and Anderson (1987), also, absorption of $\beta$-carotene with peak at $464 \mathrm{~nm}$ and $493 \mathrm{~nm}$ was reported by Shan et al (2001). 
Chlorophyll Extraction and Storage Studies on Selected Vegetables (Bitter Leaf - Vernonia Amygdalina, Pawpaw Leaf - Carica Papaya and Pumpkin Leaf - Telfairia Occidentalis)

Table3.18. Absorption maximum for bitter leaf extracted with petroleum ether stored at room temperature.

\begin{tabular}{|c|c|c|}
\hline Storage period & Wavelength of maximum absorption (nm) & Absorbance \\
\hline Initial & 474 & 1.109 \\
\hline Week 1 & 475 & 1.505 \\
\hline Week 2 & 476 & 1.538 \\
\hline Week 3 & 478 & 1.501 \\
\hline Week 4 & 496 & 1.455 \\
\hline
\end{tabular}

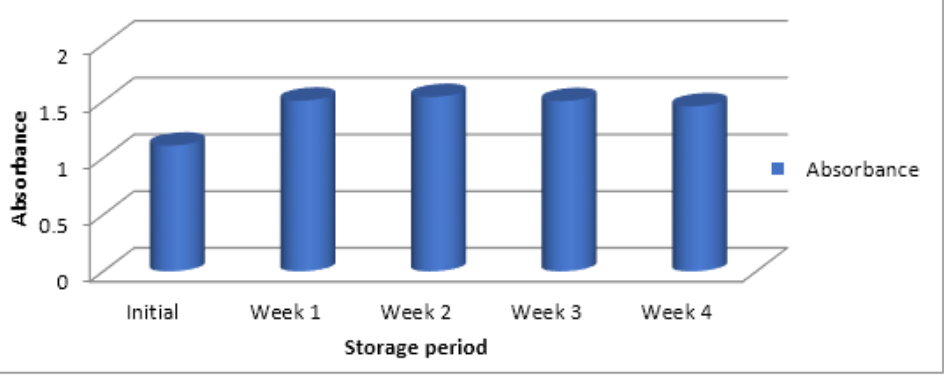

Fig3.18. Absorption maximum for bitter leaf extracted with petroleum ether stored at room temperature.

Table3.19. Absorption maximum for bitter leaf extracted with $n$-hexane stored at room temperature

\begin{tabular}{|c|c|c|}
\hline Storage period & Wavelength of maximum absorption (nm) & Absorbance \\
\hline Initial & 474 & 1.472 \\
\hline Week 1 & 475 & 1.438 \\
\hline Week 2 & 477 & 1.205 \\
\hline Week 3 & 474 & 1.550 \\
\hline Week 4 & 669 & 1.511 \\
\hline
\end{tabular}

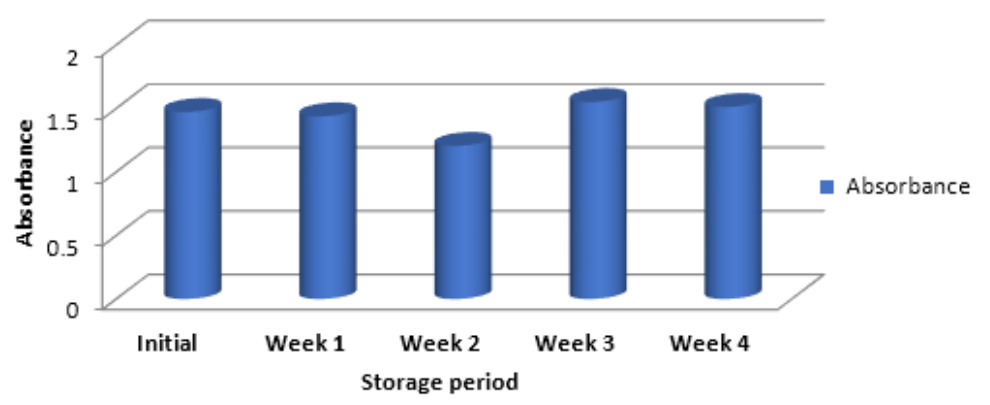

Fig3.19. Absorption maximum for bitter leaf extracted with $n$-hexane stored at room temperature

Table3.20. Absorption maximum for pumpkin leaf extracted with $n$-hexane stored at room temperature

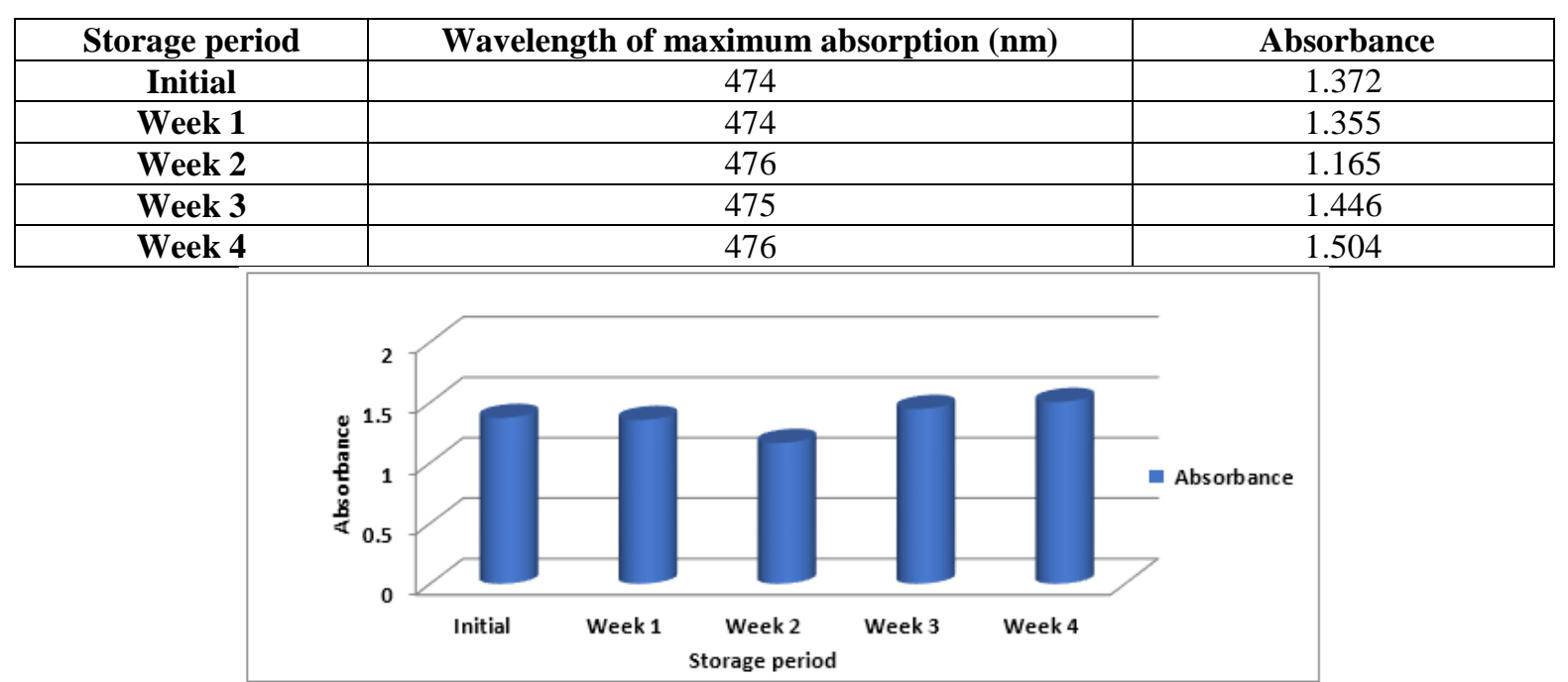

Fig3.20. Absorption maximum for pumpkin leaf extracted with $n$-hexane stored at room temperature 
Chlorophyll Extraction and Storage Studies on Selected Vegetables (Bitter Leaf - Vernonia Amygdalina, Pawpaw Leaf - Carica Papaya and Pumpkin Leaf - Telfairia Occidentalis)

With respect to bitter leaf extracted with petroleum ether (Table 3.18), bitter leaf extracted with nhexane (Table 3.19) and pumpkin leaf extracted with n-hexane (Table 3.20), the maximum peak was initially at $474 \mathrm{~nm}$. This shows the dominant presence of chlorophyll b similar to peak at $472 \mathrm{~nm}$ reported by Evans and Anderson, (1987). On storage for 4 weeks, no significant change in maximum absorption scan except in the $4^{\text {th }}$ week where there was a shift in absorption for bitter leaf extracted with petroleum ether (Table 3.18) and bitter leaf extracted with n-hexane (Table 3.19) to $496 \mathrm{~nm}$ and $669 \mathrm{~nm}$ respectively. The absorption at $496 \mathrm{~nm}$ may be due to carotenoid, as absorption of carotenoid at $493 \mathrm{~nm}$ has been reported by Shan et al, (2001).

Table3.21. Absorbance for bitter leaf extracted with deionized distilled water and $n$-hexane stored at water activity $\left(a_{w}\right) 0.33$

\begin{tabular}{|c|c|c|c|c|}
\hline & \multicolumn{2}{|c|}{$\begin{array}{c}\text { Bitter leaf extracted with deionized } \\
\text { distilled water }\end{array}$} & \multicolumn{2}{c|}{ Bitter leaf extracted with n-hexane } \\
\hline $\begin{array}{c}\text { Storage } \\
\text { Period }\end{array}$ & $\begin{array}{c}\text { Absorbance at } \\
430 \mathrm{~nm}\left(A_{430}\right)\end{array}$ & $\begin{array}{c}\text { Absorbance at } \\
660 \mathrm{~nm}\left(A_{660}\right)\end{array}$ & $\begin{array}{c}\text { Absorbance at } \\
430 \mathrm{~nm}\left(A_{430}\right)\end{array}$ & $\begin{array}{c}\text { Absorbance at } 660 \mathrm{~nm} \\
\left(A_{660}\right)\end{array}$ \\
\hline Initial & 1.495 & 1.215 & 1.102 & 1.176 \\
\hline I month & 1.816 & 1.054 & 0.087 & 0.061 \\
\hline
\end{tabular}

Table3.22. Absorbance for bitter leaf extracted with deionized distilled water and $n$ hexane stored at water activity $\left(a_{w}\right) 0.75$

\begin{tabular}{|c|c|c|c|c|}
\hline & \multicolumn{2}{|c|}{$\begin{array}{c}\text { Bitter leaf extracted with deionized } \\
\text { distilled water }\end{array}$} & \multicolumn{2}{c|}{ Bitter leaf extracted with n-hexane } \\
\hline $\begin{array}{c}\text { Storage } \\
\text { Period }\end{array}$ & $\begin{array}{c}\text { Absorbance at } \\
430 \mathrm{~nm}\left(A_{430}\right)\end{array}$ & $\begin{array}{c}\text { Absorbance at } \\
660 \mathrm{~nm}\left(A_{660}\right)\end{array}$ & $\begin{array}{c}\text { Absorbance at } \\
430 \mathrm{~nm}\left(A_{430}\right)\end{array}$ & $\begin{array}{c}\text { Absorbance at } 660 \mathrm{~nm} \\
\left(A_{660}\right)\end{array}$ \\
\hline Initial & 1.459 & 1.215 & 1.102 & 1.176 \\
\hline 1 month & 1.515 & 1.172 & 0.013 & 0.037 \\
\hline
\end{tabular}

Table3.23. Absorbance for pawpaw leaf extracted with deionized distilled water and $n$-hexane stored at water $\operatorname{activity}\left(a_{w}\right) 0.33$.

\begin{tabular}{|c|c|c|c|c|}
\hline \multirow[b]{2}{*}{$\begin{array}{l}\text { Storage } \\
\text { Period }\end{array}$} & \multicolumn{2}{|c|}{$\begin{array}{c}\text { Pawpaw leaf extracted with deionized } \\
\text { distilled water }\end{array}$} & \multicolumn{2}{|c|}{ Pawpaw leaf extracted with n-hexane } \\
\hline & $\begin{array}{c}\text { Absorbance at } \\
430 \mathrm{~nm}\left(\text { A430 }_{4}\right)\end{array}$ & $\begin{array}{c}\text { Absorbance at } \\
660 \mathrm{~nm}\left(\text { A660 }^{2}\right)\end{array}$ & $\begin{array}{c}\text { Absorbance at } \\
\text { 430nm }\left(A_{430}\right)\end{array}$ & $\begin{array}{c}\text { Absorbance at } 660 \mathrm{~nm} \\
\left(\text { A660 }^{2}\right)\end{array}$ \\
\hline Initial & 1.183 & 1.153 & 1.706 & 1.112 \\
\hline 1 month & 1.403 & 1.243 & 0.798 & 0.859 \\
\hline
\end{tabular}

Table3.24. Absorbance for pawpaw leaf extracted with deionized distilled water and $n$ hexane stored at water $\operatorname{activity}\left(a_{w}\right) 0.75$

\begin{tabular}{|c|c|c|c|c|}
\hline \multirow[b]{2}{*}{ Storage period } & \multicolumn{2}{|c|}{$\begin{array}{c}\text { Pawpaw leaf extracted with deionized } \\
\text { distilled water }\end{array}$} & \multicolumn{2}{|c|}{ Pawpaw leaf extracted with n-hexane } \\
\hline & $\begin{array}{c}\text { Absorbance at } \\
\text { 430nm (A430) }\end{array}$ & $\begin{array}{c}\text { Absorbance at } \\
660 \mathrm{~nm}\left(\text { A660 }_{66}\right)\end{array}$ & $\begin{array}{c}\text { Absorbance at } \\
\text { 430nm }(\text { A } 430)^{4}\end{array}$ & $\begin{array}{c}\text { Absorbance at 660nm } \\
\left(\text { A660 }_{66}\right)\end{array}$ \\
\hline Initial & 1.183 & 1.153 & 1.706 & 1.112 \\
\hline 1 month & 1.390 & 1.677 & 0.565 & 0.558 \\
\hline
\end{tabular}

Table3.25. Absorbance for pumpkin leaf extracted with deionized distilled water and $n$-hexane stored at water activity $\left(a_{w}\right) 0.33$

\begin{tabular}{|c|c|c|c|c|}
\hline & \multicolumn{2}{|c|}{$\begin{array}{l}\text { Pumpkin leaf extracted with } \\
\text { deionized distilled water }\end{array}$} & \multicolumn{2}{|c|}{ Pumpkin leaf extracted withn-hexane } \\
\hline $\begin{array}{l}\text { Storage } \\
\text { Period }\end{array}$ & $\begin{array}{c}\text { Absorbance at } \\
\text { 430nm }\left(A_{430}\right)\end{array}$ & $\begin{array}{c}\text { Absorbance at } \\
660 \mathrm{~nm}\left(A_{660}\right)\end{array}$ & $\begin{array}{c}\text { Absorbance at } \\
430 \mathrm{~nm}\left(\mathrm{~A}_{430}\right)\end{array}$ & $\begin{array}{c}\text { Absorbance at 660nm } \\
\left(A_{660}\right)\end{array}$ \\
\hline Initial & 1.562 & 1.439 & 0.788 & 0.601 \\
\hline 1 month & 1.795 & 0.395 & 0.069 & 0.012 \\
\hline
\end{tabular}


Chlorophyll Extraction and Storage Studies on Selected Vegetables (Bitter Leaf - Vernonia Amygdalina, Pawpaw Leaf - Carica Papaya and Pumpkin Leaf - Telfairia Occidentalis)

Table3.26. Absorbance for pumpkin leaf extracted with deionized distilled water and $n$-hexane stored at water activity $\left(a_{w}\right) 0.75$

\begin{tabular}{|c|c|c|c|c|}
\hline & \multicolumn{2}{|c|}{$\begin{array}{c}\text { Pumpkin leaf deionized distilled } \\
\text { water extract }\end{array}$} & \multicolumn{2}{|c|}{ Pumpkin leaf n-hexane extract } \\
\hline $\begin{array}{l}\text { Storage } \\
\text { Period }\end{array}$ & $\begin{array}{c}\text { Absorbance at } \\
430 \mathrm{~nm}\left(\mathrm{~A}_{430}\right)\end{array}$ & $\begin{array}{c}\text { Absorbance at } \\
660 \mathrm{~nm}\left(\text { A660 }_{6}\right)\end{array}$ & $\begin{array}{c}\text { Absorbance at } \\
430 \mathrm{~nm}\left(\mathrm{~A}_{430}\right)\end{array}$ & $\begin{array}{c}\text { Absorbance at 660nm } \\
\left(A_{660}\right)\end{array}$ \\
\hline Initial & 1.562 & 1.439 & 0.788 & 0.601 \\
\hline 1 month & 1.684 & 1.728 & 0.064 & 0.005 \\
\hline
\end{tabular}

For bitter leaf extracted with deionized distilled water and stored at $\mathrm{a}_{\mathrm{w}} 0.33$ and $\mathrm{a}_{\mathrm{w}} 0.75$ (Tables 3.21 and 3.22 ), initially before storage, absorbance at $430 \mathrm{~nm}$ was 1.495 . After one month of storage, it was observed that the absorbance value for extract stored at $\mathrm{a}_{\mathrm{w}} 0.33$ was 1.816 which was higher than 1.515 measured for extract stored at $a_{w} 0.75$. This may be due to the fast conversion of chlorophyll $b$ to chlorophyll a in extracts stored at $\mathrm{a}_{\mathrm{w}} 0.33$. Similarly, for pawpaw leaf extracted with deionized distilled water stored at $\mathrm{a}_{\mathrm{w}} 0.33$ and $\mathrm{a}_{\mathrm{w}} 0.75$ (Tables 3.23 and 3.24) and pumpkin leaf extracted with deionized distilled water stored at $\mathrm{a}_{\mathrm{w}} 0.33$ and $\mathrm{a}_{\mathrm{w}} 0.75$ (Tables 3.25 and 3.26), a similar trend was observed. Therefore, a similar explanation is indicated. Thus, it can be said that for deionized distilled water, which was a polar solvent, the lower the water activity in which extracts were stored, the higher the amount of chlorophyll b converted to chlorophyll a.

With respect to absorbance at $660 \mathrm{~nm}$, for bitter leaf extracted with deionized distilled water and stored at $a_{w} 0.33$ and $a_{w} 0.75$ (Tables 3.21 and 3.22) the initial absorbance was 1.215. After one month of storage, it was observed that absorbance for extract stored at $\mathrm{a}_{\mathrm{w}} 0.75$ was 1.172 which was higher than 1.054 measured for extract stored at $\mathrm{a}_{\mathrm{w}} 0.33$. This may be due to the formation of pheophytin a from the degradation of chlorophyll a when stored at $\mathrm{a}_{\mathrm{w}} 0.75$. Similarly, for pawpaw leaf extracted with deionized distilled water stored at $\mathrm{a}_{\mathrm{w}} 0.33$ and $\mathrm{a}_{\mathrm{w}} 0.75$ (Tables 3.23 and 3.24) and pumpkin leaf extracted with deionized distilled water stored at $\mathrm{a}_{\mathrm{w}} 0.33$ and $\mathrm{a}_{\mathrm{w}} 0.75$ (Tables 3.25 and 3.26) a similar trend was observed. Therefore, a similar explanation is indicated. Thus, it can be said that for deionized distilled water, which was a polar solvent, the higher the water activity in which extracts were stored, the higher the amount of pheophytin a formed. For bitter leaf extracted with n-hexane stored at water activity of $\mathrm{a}_{\mathrm{w}}$ of 0.33 and 0.75 (Tables 3.22 and 3.23), initially before storage, absorbance at 430nm was 1.102 . After one month of storage, it was observed that the absorbance for extract stored at $\mathrm{a}_{\mathrm{w}} 0.33$ was 0.087 which was higher than 0.013 measured for extract stored at $\mathrm{a}_{\mathrm{w}} 0.75$. This implies that the degradation of chlorophyll a was faster for extract stored at $\mathrm{a}_{\mathrm{w}} 0.75$. Similarly, for pawpaw leaf extracted with $\mathrm{n}$-hexane and stored at $\mathrm{a}_{\mathrm{w}} 0.33$ and $\mathrm{a}_{\mathrm{w}} 0.75$ (Tables 3.23 and 3.24) and pumpkin leaf extracted with n-hexane stored at $\mathrm{a}_{\mathrm{w}} 0.33$ and $\mathrm{a}_{\mathrm{w}} 0.75$ (Tables 3.25 and 3.26) a similar trend was observed. Accordingly, a similar explanation is indicated. Thus, it can be said that for n-hexane a non-polar solvent, the higher the water activity in which extracts were stored, the faster the degradation of chlorophyll a .

With respect to absorbance at $660 \mathrm{~nm}$ for bitter leaf extracted with $\mathrm{n}$-hexane, the initial absorbance was 1.076. after one month of storage, it was observed that absorbance for extract stored at $\mathrm{a}_{\mathrm{w}} 0.33$ was 0.061 which was higher than 0.037 measured for extract stored at $\mathrm{a}_{\mathrm{w}} 0.75$. This showed that the degradation of pheophytin a was faster for extracts stored at $\mathrm{a}_{\mathrm{w}} 0.75$. Similarly, for pawpaw leaf extracted with $\mathrm{n}$ hexane and stored at $a_{w} 0.33$ and $a_{w} 0.75$ (Tables 3.23 and 3.24) and pumpkin leaf extracted with nhexane stored at $\mathrm{a}_{\mathrm{w}} 0.33$ and $\mathrm{a}_{\mathrm{w}} 0.75$ (Tables 3.25 and 3.26) a similar trend was also observed. Thus, it can be said that for $n$-hexane (a nonpolar solvent), the higher the water activity in which extracts are stored, the faster the degradation of pheophytin a in extracts.

Table3.27. Absorption maximum, $p H$ and specific gravity of bitter leaf extracted with deionized distilled water stored at water activity $\left(a_{w}\right)$ of 0.33

\begin{tabular}{|c|c|c|c|c|}
\hline Storage period & $\begin{array}{c}\text { Wavelength of maximum } \\
\text { absorption }(\mathbf{n m})\end{array}$ & Absorbance & $\boldsymbol{p H}$ & Specific gravity \\
\hline Initial & 467 & 1.064 & 6.15 & 1.028 \\
\hline One month & 673 & 0.220 & 4.12 & 0.981 \\
\hline
\end{tabular}


Chlorophyll Extraction and Storage Studies on Selected Vegetables (Bitter Leaf - Vernonia Amygdalina, Pawpaw Leaf - Carica Papaya and Pumpkin Leaf - Telfairia Occidentalis)

Table 3.28: Absorption maximum, $\mathrm{pH}$ and specific gravity for bitter leaf extracted with deionized distilled water stored at water activity $\left(a_{w}\right)$ of 0.75

\begin{tabular}{|c|c|c|c|c|}
\hline Storage Period & $\begin{array}{c}\text { Wavelength of maximum } \\
\text { absorption }(\mathbf{n m})\end{array}$ & Absorbance & $\boldsymbol{p H}$ & Specific gravity \\
\hline Initial & 473 & 1.473 & 6.61 & 1.120 \\
\hline One month & 448 & 0.286 & 4.97 & 0.660 \\
\hline
\end{tabular}

Table3.29. Absorption maximum, $p H$ and specific gravity of bitter leaf extracted with $n$-hexane stored at water activity $\left(a_{w}\right)$ of 0.33

\begin{tabular}{|c|c|c|c|c|}
\hline Storage period & $\begin{array}{c}\text { Wavelength of maximum } \\
\text { absorption }(\mathbf{n m})\end{array}$ & Absorbance & $\boldsymbol{p H}$ & Specific gravity \\
\hline Initial & 467 & 1.064 & 6.15 & 1.028 \\
\hline One month & 331 & 0.801 & 8.79 & 0.981 \\
\hline
\end{tabular}

Table3.30. Absorption maximum, $\mathrm{pH}$ and specific gravity for bitter leaf extracted with $n$-hexane stored at water activity of 0.75

\begin{tabular}{|c|c|c|c|c|}
\hline Storage period & $\begin{array}{c}\text { Wavelength of maximum } \\
\text { absorption }(\mathbf{n m})\end{array}$ & Absorbance & $\boldsymbol{p H}$ & Specific gravity \\
\hline Initial & 473 & 1.473 & 6.61 & 1.120 \\
\hline One month & 324 & 0.182 & 7.96 & 0.660 \\
\hline
\end{tabular}

Table3.31. Absorption maximum, $\mathrm{pH}$ and specific gravity of pumpkin leaf extracted with $n$-hexane stored at water activity $\left(a_{w}\right)$ of 0.33

\begin{tabular}{|c|c|c|c|c|}
\hline Storage Period & $\begin{array}{c}\text { Wavelength of maximum } \\
\text { absorption }(\text { nm })\end{array}$ & Absorbance & $p H$ & Specific gravity \\
\hline Initial & 473 & 1.400 & 6.67 & 1.120 \\
\hline One month & 671 & 0.915 & 4.49 & 0.660 \\
\hline
\end{tabular}

Table3.32. Absorption maximum, $\mathrm{pH}$ and specific gravity of pumpkin leaf extracted with $n$-hexane stored at water activity $\left(a_{w}\right)$ of 0.75

\begin{tabular}{|c|c|c|c|c|}
\hline $\begin{array}{c}\text { Storage } \\
\text { Period }\end{array}$ & $\begin{array}{c}\text { Wavelength of maximum } \\
\text { absorption }(\mathbf{n m})\end{array}$ & Absorbance & $\boldsymbol{p H}$ & Specific gravity \\
\hline Initial & 473 & 1.400 & 6.67 & 1.120 \\
\hline One month & 332 & 0.532 & 7.75 & 0.660 \\
\hline
\end{tabular}

Table3.33. Absorption maximum, $\mathrm{pH}$ and specific gravity for pumpkin leaf extracted with deionized distilled water stored at water activity $\left(a_{w}\right)$ of 0.33

\begin{tabular}{|c|c|c|c|c|}
\hline $\begin{array}{c}\text { Storage } \\
\text { Period }\end{array}$ & $\begin{array}{c}\text { Wavelength of maximum } \\
\text { absorption }(\mathbf{n m})\end{array}$ & Absorbance & $\boldsymbol{p H}$ & Specific gravity \\
\hline Initial & 473 & 2.016 & 6.68 & 0.993 \\
\hline One month & 672 & 0.703 & 4.84 & 0.981 \\
\hline
\end{tabular}

Table3.34. Absorption maximum, $\mathrm{pH}$ and specific gravity for pumpkin leaf extracted with deionized distilled water stored at water activity of 0.75

\begin{tabular}{|c|c|c|c|c|}
\hline Storage period & $\begin{array}{c}\text { Wavelength of maximum } \\
\text { absorption }(\mathbf{n m})\end{array}$ & Absorbance & $\boldsymbol{p H}$ & Specific gravity \\
\hline Initial & 473 & 1.016 & 6.68 & 0.993 \\
\hline One month & 333 & 0.794 & 7.22 & 0.962 \\
\hline
\end{tabular}

For bitter leaf extracted with deionized distilled water and stored at $a_{w} 0.33$ (Table 3.27), the initial maximum absorption was at $467 \mathrm{~nm}$. This may be ascribed to the presence of chlorophyll b in the extract. After one month of storage, the maximum absorption shifted to $673 \mathrm{~nm}$, the shift may be because of the conversion of chlorophyll $b$ to chlorophyll a. An absorption peak for chlorophyll $b$ at $472 \mathrm{~nm}$ and $653 \mathrm{~nm}$ was also reported by Evans and Anderson (1987). A similar trend was observed for bitter leaf extracted with n-hexane and stored at $a_{w} 0.33$ (Table 3.29), pumpkin leaf extracted with n-hexane and stored at $\mathrm{a}_{\mathrm{w}} 0.33$ (Table 3.31) and pumpkin leaf extracted with deionized distilled water and stored at $\mathrm{a}_{\mathrm{w}}$ 0.33(Table 3.33) and hence a similar explanation is indicated. For bitter leaf extracted with deionized distilled water and stored at $a_{w} 0.75$ (Table 3.28), the initial maximum absorption was at $467 \mathrm{~nm}$. After 
Chlorophyll Extraction and Storage Studies on Selected Vegetables (Bitter Leaf - Vernonia Amygdalina, Pawpaw Leaf - Carica Papaya and Pumpkin Leaf - Telfairia Occidentalis)

one month of storage, maximum absorption shifted to $331 \mathrm{~nm}$. The shift may be due to the degradation of chlorophyll $b$ to a conjugated compound which absorbed at $331 \mathrm{~nm}$. A similar trend was observed for bitter leaf extracted with $n$-hexane and stored at $\mathrm{a}_{\mathrm{w}} 0.75$ (Table 3.30), pumpkin leaf extracted with $\mathrm{n}$ hexane and stored at $\mathrm{a}_{\mathrm{w}} 0.75$ (Table 3.32) and pumpkin leaf extracted with deionized distilled water and stored at $\mathrm{a}_{\mathrm{w}} 0.75$ (Table 3.34). Hence, a similar explanation is indicated.

The chemical kinetics of all the reactions are $\mathrm{pH}$ dependent. Therefore, the interaction between the different components of the extracts may be $\mathrm{pH}$ dependent too. This reaction may affect the conversion and degradation of chlorophyll from one form to the other. Absorbance values for bitter leaf extracted with deionized distilled water and stored at $\mathrm{a}_{\mathrm{w}} 0.33$ (Table 3.27) decreased from 1.06 at $467 \mathrm{~nm}$ to 0.220 at $673 \mathrm{~nm}$. The reduction in absorbance value may have been followed by a change in $\mathrm{pH}$ from 6.15 initially after extraction to 4.12 after one month of storage. This may have resulted in decrease in chlorophyll $\mathrm{b}$ in the extract. Furthermore, the initial specific gravity was 1.028 and after one month of storage decreased to 0.981 . The difference between the initial specific gravity and the specific gravity after one month of storage is an indication of how much chlorophyll $b$ and possibly other components of the extract have been converted. A similar trend was observed for bitter leaf extracted with n-hexane and stored at $a_{w} 0.33$ (Table 3.29), pumpkin leaf extracted with $n$-hexane and stored at $a_{w} 0.33$ (Table 3.31 ) and pumpkin leaf extracted with deionized distilled water and stored at $\mathrm{a}_{\mathrm{w}} 0.33$ (Table 3.33). For bitter leaf extracted with deionized distilled water and stored at $\mathrm{a}_{\mathrm{w}} 0.75$ (Table 3.28) absorbance decreased from 1.064 at $467 \mathrm{~nm}$ to 0.801 at $331 \mathrm{~nm}$. The reduction in absorbance may have been followed by change in $\mathrm{pH}$ from 6.15 initially after extraction to 8.79 after one month of storage. A similar trend was observed for bitter leaf extracted with $n$-hexane and stored at $\mathrm{a}_{\mathrm{w}} 0.75$ (Table 3.30), pumpkin leaf extracted with $n$-hexane and stored at $a_{w} 0.75$ (Table 3.32) and pumpkin leaf extracted with deionized distilled water and stored at $a_{w} 0.75$ (Table 3.34). Accordingly, a similar explanation is indicated.

Table3.35. Absorption maximum, $\mathrm{pH}$ and specific gravity for pawpaw leaf extracted with deionized distilled water stored at water activity $\left(a_{w}\right)$ of 0.33

\begin{tabular}{|c|c|c|c|c|}
\hline Storage Period & $\begin{array}{c}\text { Wavelength of maximum } \\
\text { absorption }(\mathrm{nm})\end{array}$ & Absorbance & $p H$ & Specific gravity \\
\hline Initial & 431 & 1.034 & 6.08 & 0.986 \\
\hline One month & 331 & 0.805 & 4.68 & 0.981 \\
\hline
\end{tabular}

Table3.36. Absorption maximum, $\mathrm{pH}$ and specific gravity for pawpaw leaf extracted with deionized distilled water stored at water activity of 0.75

\begin{tabular}{|c|c|c|c|c|}
\hline Storage Period & $\begin{array}{c}\text { Wavelength of maximum } \\
\text { absorption }(\mathrm{nm})\end{array}$ & Absorbance & $p H$ & Specific gravity \\
\hline Initial & 431 & 1.034 & 6.08 & 0.986 \\
\hline One month & 331 & 0.642 & 4.02 & 0.981 \\
\hline
\end{tabular}

For pawpaw leaf extracted with deionized distilled water and stored at $\mathrm{a}_{\mathrm{w}} 0.33$ (Table 3.35), the initial maximum absorption was at $431 \mathrm{~nm}$. This could be related to the presence of chlorophyll a in the extract. After one month of storage, the maximum absorption shifted to $331 \mathrm{~nm}$. The shift may be because of the conversion of chlorophyll a to an unknown compound which absorbed at $331 \mathrm{~nm}$. This compound was very likely a conjugated compound because of its strong absorption at $331 \mathrm{~nm}$, which is in the UV region of the electromagnetic spectrum. It is reported that conjugated compounds tend to show strong absorption in the UV region of the electromagnetic spectrum (Masayoshi, 2002). The absorption of chlorophyll a at $438 \mathrm{~nm}$ and $670 \mathrm{~nm}$ and chlorophyll b at $469 \mathrm{~nm}$ and $650 \mathrm{~nm}$ was reported by Beatrice $e t$ al (2000). A similar trend was observed for pawpaw leaf extracted with deionized distilled water and stored at $\mathrm{a}_{\mathrm{w}} 0.75$ (Table 3.36).

The chemical kinetics of all the reactions are $\mathrm{pH}$ dependent. Hence, the interaction between the different components of chlorophyll extracts may be $\mathrm{pH}$ dependent too. This reaction may affect the conversion and degradation of chlorophyll from one form to the other. Absorbance values for pawpaw leaf extracted with deionized distilled water and stored at $\mathrm{a}_{\mathrm{w}} 0.33$ (Table 3.35) decreased from 1.034 at $431 \mathrm{~nm}$ to 0.805 at $331 \mathrm{~nm}$. The reduction in absorbance value may have been followed by change in $\mathrm{pH}$ from 6.08 initially after extraction to 4.68 after one month of storage. This may have resulted in the transformation of in chlorophyll a. Furthermore, the initial specific gravity was 0.986 and after one 
Chlorophyll Extraction and Storage Studies on Selected Vegetables (Bitter Leaf - Vernonia Amygdalina, Pawpaw Leaf - Carica Papaya and Pumpkin Leaf - Telfairia Occidentalis)

month of storage decreased to 0.981 . The difference between the initial specific gravity and the specific gravity after one month of storage is an indication of how much chlorophyll a among other entities has been converted. A similar trend was observed for pawpaw leaf extracted with deionized distilled water and stored at $\mathrm{a}_{\mathrm{w}} 0.75$ (Table 3.36).

Table3.37. Absorption maximum, $p H$ and specific gravity for pawpaw leaf extracted with $n$-hexane stored at water activity $\left(a_{w}\right)$ of 0.33

\begin{tabular}{|c|c|c|c|c|}
\hline Pawpaw leaf in n-hexane & $\begin{array}{c}\text { Wavelength of maximum } \\
\text { absorption }(\mathbf{n m})\end{array}$ & Absorbance & pH & Specific gravity \\
\hline Initial & 670 & 2.236 & 6.42 & 1.106 \\
\hline One month & 473 & 0.570 & 6.23 & 0.660 \\
\hline
\end{tabular}

Table3.38. Absorption maximum, $\mathrm{pH}$ and specific gravity for pawpaw leaf extracted with $n$-hexane stored at water activity $\left(a_{w}\right)$ of 0.75

\begin{tabular}{|c|c|c|c|c|}
\hline $\begin{array}{c}\text { Pawpaw leaf in } \boldsymbol{n -} \\
\text { hexane }\end{array}$ & $\begin{array}{c}\text { Wavelength of maximum } \\
\text { absorption }(\mathbf{n m})\end{array}$ & Absorbance & $\boldsymbol{p H}$ & Specific gravity \\
\hline Initial & 670 & 2.236 & 6.42 & 1.106 \\
\hline One month & 669 & 0.896 & 6.07 & 0.660 \\
\hline
\end{tabular}

For pawpaw leaf extracted with $n$-hexane and stored at $\mathrm{a}_{\mathrm{w}} 0.33$ (Table 3.37), the initial maximum absorption was at $670 \mathrm{~nm}$. This may be attributed to the presence of chlorophyll a in the extract. After one month of storage, the maximum absorption shifted to $473 \mathrm{~nm}$. This may be related to the presence of chlorophyll $b$. The shift may be as a result of the degradation of chlorophyll a. An absorption peak for chlorophyll b at 472nm and 653nm was also reported by Evans and Anderson, (1987). However, for pawpaw leaf extracted with $\mathrm{n}$-hexane and stored at $\mathrm{a}_{\mathrm{w}} 0.75$ (Table 3.38), the initial maximum absorption was at $670 \mathrm{~nm}$. After one month of storage, there was no significant change in maximum absorption. This may be due to the dominant presence of chlorophyll a, which may have resulted from the conversion of chlorophyll $\mathrm{b}$ to chlorophyll $\mathrm{a}$.

The chemical kinetics of all the reactions are $\mathrm{pH}$ dependent. Hence, the interaction between the different components of chlorophyll extracts may be $\mathrm{pH}$ dependent too. This reaction may affect the conversion and degradation of chlorophyll from one form to the other. Absorbance values for pawpaw leaf extracted with $\mathrm{n}$-hexane and stored at $\mathrm{a}_{\mathrm{w}} 0.33$ (Table 3.37) decreased from 2.206 at $670 \mathrm{~nm}$ to 0.570 at $473 \mathrm{~nm}$. The reduction in absorbance value may have been followed by change in $\mathrm{pH}$ from 6.42 initially after extraction to 6.23 after one month of storage. This resulted in increase in chlorophyll b content. Furthermore, the initial specific gravity was 1.106 and after one month of storage decreased to 0.660 , the difference between the initial specific gravity and the specific gravity after one month of storage is an indication of how much chlorophyll $b$ is left after one month of storage. A similar trend was observed for pawpaw leaf extracted with $n$-hexane and stored at $\mathrm{a}_{\mathrm{w}} 0.75$ (Table 3.38).

Overall, this study has shown from absorbance at 660nm that chlorophyll a was converted to pheophytin a during extraction due to the release of cellular acids as can be deduced from low $\mathrm{pH}$ values. Based on absorbance measured at $430 \mathrm{~nm}$ and $660 \mathrm{~nm}$, extraction of chlorophyll a and pheophytin a from vegetable leaves would seem to depend on the polarity of the solvents used for extraction. The order of polarity was deionized distilled water $>$ ethanol $>$ acetone $>$ petroleum ether $>$ n-hexane. UV-visible scan for extracts stored at room temperature, initially after extraction indicates the presence of chlorophyll a at $670 \mathrm{~nm}$ which did not change much during storage except for n-hexane extracts of bitter leaf and pumpkin leaf and petroleum ether extracts of bitter leaf which were dominated by chlorophyll $b$ at $474 \mathrm{~nm}$. The different extracts showed increase and decrease in absorbance values during storage. Possibly, conversion of chlorophyll b to chlorophyll a, degradation of chlorophyll a to pheophytin a and degradation of pheophytin a to pheophorbide occurred. UV-visible scan for extracts stored at water activity $\left(\mathrm{a}_{\mathrm{w}}\right)$ of 0.33 point to the conversion of chlorophyll $\mathrm{b}$ at $467 \mathrm{~nm}$ and $473 \mathrm{~nm}$ to chlorophyll a at $448 \mathrm{~nm}$ and $671 \mathrm{~nm}$ after one month of storage. UV-visible scan for extracts stored at water activity $\left(\mathrm{a}_{\mathrm{w}}\right)$ of 0.75 suggests the conversion of chlorophyll a and chlorophyll $b$ to compound which absorbs at $331 \mathrm{~nm}$ or $333 \mathrm{~nm}$. $\mathrm{pH}$ values for all extracts initially after extraction was below 7, that is acidic $\mathrm{pH}$. After one month of storage at water activity of $\left(\mathrm{a}_{\mathrm{w}}\right)$ of $0.33, \mathrm{pH}$ remained acidic and at water activity $\left(\mathrm{a}_{\mathrm{w}}\right)$ of 0.75 , $\mathrm{pH}$ became slightly alkaline. The specific gravity of all extracts reduced during storage. 


\section{CONCLUSiON}

This study has revealed that the different solvents used in the extraction of the various samples were effective to different degrees with respect to the various forms of chlorophyll. Storage changes were observed at room temperature with respect to absorbance values. Water activity $\left(a_{w}\right)$ also affected the UV-Visible characteristics of the various extracts. $\mathrm{pH}$ values also change during storage sometimes towards alkalinity or other times towards acidity. Changes in specific gravity value may be relative to biochemical transformation of the component of the extracts which include the pigment (chlorophyll and it various forms or derivatives.

\section{REFERENCES}

[1] Akoroda, M. O., (1990). Ethnobatany of Telfairia occidentalis among Igbos of Nigeria. Economic Botany, 44 (1).29-39.

[2] Atwell, B.J., Kriedemann, P.E., and Turnbull, C.G., (1999). Plants in action. Macmillan ed., Melbourne Australia., 1

[3] Burkill, H. M. (1985). The useful plants of West Tropical Africa. Vol 1. Kew: Royal Botanic Gardens.

[4] Cady, J. B., and Morgan, W. S. (1948). Treatment of chronic ulcers with chlorophyll: review of a series of fifty cases, The American Journal of Surgery, 75(4).562-569.

[5] Carpenter, E. B., (1949). Clinical experiences with chlorophyll preparations: with reference to chronic osteomyelitis and chronic ulcers, The American Journal of Surgery, 77(2).167-171.

[6] Chen, M., Schliep, M., Willows, R. D., Cai, Z., Neilan, B. A.., Scheer, H., (2010). A Red-Shifted Chlorophyll, Science, 329(5997)1318-1319.

[7] Closs, G. L., Dutler, H., and Hannah, J., (1960). The total synthesis of chlorophyll, Journal of the American Chemical Society, 82(14).3800-3802.

[8] Evans, J.R., and Anderson, J.M., (1987). Absolute absorption and relative flouresence excitation spectra of the 5 major chlorophyll protein complexes from spinach thlakoid membranes. Biochem. Biophys. Acta, 892: 75-82

[9] English Wikipedia (2015). Chlorophyll; Retrieved from; http://en.wikipedia.org/wiki/Chlorophyll on the 8/05/2015

[10] Esiaba, R.O., (1982). Cultivating the fluted pumpkin in Nigeria. World crops, 34(2).70-72.

[11] Horwitz, B., (1951). Role of chlorophyll in proctology, The American Journal of Surgery, 81(1).81-84

[12] Humphrey, A. M., (2004). Chlorophyll as a color and functional ingredient, Journal of Food Science, 69(5).422-425

[13] Jabr, F., (2010). A New Form of Chlorophyll?_Scientific American. Retrieved from; www.wikipedia.org on the $30 / 04 / 2014$

[14] Jeffrey, S.W., Mantoura, R.F.C., and Wright, S.W., (1996). Phytoplankton Pigments in Oceanography: Guidelines to Modern Methods, UNESCO Publishing, Paris, p.1.

[15] Kaewsuksaeng, S., Yamauchi, N., Funamoto, Y., and Shigyo, M.K., (2006). Effect of Mg dechelation activity on chlorophyll degradation in stored Broccoli florets.

[16] Kafaru, E. Immense Help From Nature's Workshop. Elika Health Services Ltd, Academic Press Plc. Lagos, Nigeria, 1994: 1-27.

[17] Krishna, K.L., Paridhavi, M., and Patel, J.A. Review on nutritional, medicinal and pharmacological properties of papaya (carica papaya Linn.) natural product radiance. Indian Journal of Natural Products and Resources (IJNPR), 2008; 7(4): 364-373

[18] Masayoshi, N., (2002). The science of colour. Baifukan. P108.

[19] Olson, J.M., (2006). "Photosynthesis in the Archean era". Photosynthesis Research 88 (2): 109-17.

[20] Raven, P.H., Evert, R.F., and Eichhorn, S.E., (2005). "Photosynthesis, Light, and Life".Biology of Plants, 7th ed. W.H. Freeman. pp. $119-127$

[21] Scheer, H., (1991). Chlorophylls, H. Scheer Ed., CRC Press, Boca Raton, FL, p1.

[22] Scheer, H., (2003). Light-Harvesting Antennas in Photosynthesis, B. R. Green, W. W.Parson Eds., Kluwer Academic Publishers, Dordrecht, p. 29.

[23] Scheer, H., (1991). in Chlorophylls, Ed. CRC Press, Boca Raton, p. 3.

[24] Scheer, H., Grimm, B., Porra, R., and Rudigger, W., (2006). Chlorophylls and Bacteriochlorophylls, Ed. Springer, Dordrecht, p.1.

[25] Shan, J., Wang, J., Ruan, X., Li, L., Gong, y., Zhao, N., and Kuang, T., (2001) 
Chlorophyll Extraction and Storage Studies on Selected Vegetables (Bitter Leaf - Vernonia Amygdalina, Pawpaw Leaf - Carica Papaya and Pumpkin Leaf - Telfairia Occidentalis)

[26] Shioi, Y., and Takamiya, K., (1996). Enzymatic conversion of pheophorbide a to the precursor of pyropheophorbide a in leaves of Chenopodium album, Plant Cell Physiology, 37(8).1143-1149.

[27] Smith, L. W., and Livingston, A. E., (1945). Wound healing: an experimental study of water soluble chlorophyll derivatives in conjunction with various antibacterial agents, The American Journal of Surgery, 67(1).30-39.

[28] Spears, K., (1988). Developments in food colourings: the natural alternatives, Trends in Biotechnology, 6(11).283-288

[29] Takamiya, K., and Shioi, Y., (1996). Enzymatic conversion of pheophorbide a to the precursor of pyropheophorbide a in leaves of Chenopodium album, Plant Cell Physiology, 37(8).1143-1149.

[30] Timberlake, C.F., and Henry, B.S., (1986). Plant pigments as natural food colours, Endeavour, 10(1).31-36.

[31] WikiDoc(2015).Chlorophyll;Retrievedon15/12/2015 from https:/www.wikidoc.org/index.php/Chlorophyll

[32] Woodward, R. B., Ayer, W. A., Beaton, J. M., Bickelhaupt, F., Bonnett, R., Buchschacher, P., (1960). Formal Synthesis of Chlorophyll a,Retrieved from; http://www.synarchive.com/syn/24 on 5/05/2014

[33] Yeap, S.K., Ho, W.H., Beh, B.K., Liang, W.S., Ky, H., Hadi, A., Yousr, N., and Alitheen, N.B., (2010). Vernonia amygdalina, an ethnoveterinary and ethnomedical used green vegetable with multiple bioactivities, Journal of Medicinal Plants Research, 4(25).2787-2812.

[34] Zvezdanović, J., Cvetić, T., Veljović-Jovanović, S. and Marković, D., (2009). Chlorophyll bleaching by UV- irradiation in vitro and in situ: Absorption and fluorescence studies, Radiation Physics and Chemistry., 78:25 - 32 .

Citation: Irede, L. Egwonor, Asishana P. Onivefu, "Chlorophyll Extraction and Storage Studies on Selected Vegetables (Bitter Leaf - Vernonia Amygdalina, Pawpaw Leaf - Carica Papaya and Pumpkin Leaf - Telfairia Occidentalis)", International Journal of Advanced Research in Chemical Science, 7(8), pp. 4061. DOI: https:// doi.org/10.20431/2349-0403.0708005

Copyright: () 2020 Authors, this is an open-access article distributed under the terms of the Creative Commons Attribution License, which permits unrestricted use, distribution, and reproduction in any medium, provided the original author and source are credited. 